\title{
Overlapping stimulons arising in response to divergent stresses in Escherichia coli
}

\author{
Huijing Wang ${ }^{1, \dagger}, *$ \\ GW McElfresh ${ }^{1, *}, *$ \\ Nishantha Wijesuriya ${ }^{2}$, \\ Adam Podgorny ${ }^{1}$, \\ Andrew D. Hecht ${ }^{2, \S}$, \\ J. Christian J. Ray ${ }^{1,2,9, \ldots+\#}$ \\ *Equal contribution. \\ †Present address: \\ University of Pittsburgh, School of Medicine \\ Department of Computational and Systems Biology \\ 3501 Fifth Avenue \\ 10051-7A Biomedical Science Tower 3 \\ Pittsburgh, PA 15260 USA \\ †Present address: \\ Oregon National Primate Research Center \\ Oregon Health and Science University \\ Beaverton, OR 97006 USA \\ \#Present address: \\ Inscripta \\ 5500 Central Avenue \\ Boulder, CO 80301 USA
}

${ }^{\circledR}$ Corresponding author.

Research conducted at the following address:

${ }^{1}$ Center for Computational Biology

${ }^{2}$ Department of Molecular Biosciences

University of Kansas

2030 Becker Dr.

Lawrence, KS 66047

USA

Email: christian.ray@inscripta.com 


\begin{abstract}
Cellular responses to stress can cause a similar change in some facets of fitness even if the stresses are different. Lactose as a sole carbon source for Escherichia coli is an established example: too little causes starvation while excessive lactose import causes toxicity as a side-effect. In an E. coli strain that is robust to osmotic and ionic differences in growth media, B REL606, the rate of antibiotic-tolerant persister formation is elevated in both starvation-inducing and toxicity-inducing concentrations of lactose in comparison to less stressful intermediate concentrations. Such similarities between starvation and toxification raise the question of how much the global stress response stimulon differs between them. We hypothesized that a common stress response is conserved between the two conditions, but that a previously shown threshold driving growth rate heterogeneity in a lactose-toxifying medium would reveal that the growing fraction of cells in that medium to be missing key stress responses that curb growth. To test this, we performed RNAseq in three representative conditions for differential expression analysis. In comparison to nominally unstressed cultures, both stress conditions showed global shifts in gene expression, with informative similarities and differences. Functional analysis of pathways, gene ontology terms, and clusters of orthogonal groups revealed signatures of overflow metabolism, membrane component shifts, and altered cytosolic and periplasmic contents in toxified cultures. Starving cultures showed an increased tendency toward stringent response-like regulatory signatures. Along with other emerging evidence, our results show multiple possible pathways to stress responses, persistence, and possibly other phenotypes. These results suggest a set of overlapping responses that drives emergence of stress-tolerant phenotypes in diverse conditions.
\end{abstract}




\section{Introduction}

Fitness and survival of a single-celled species across diverse environments incur classic trade-offs between metabolic costs and improvement of survival probability: an effective response in one environment may incur penalties in another. Mesophilic bacteria have adapted to life in intermediate conditions where several dimensions of the cellular environment can readily cause stress, such as excessively high or low temperatures, acidity, nutrients, osmotic pressure, chemical concentrations, and so on. In the lifecycle of an enteric bacterium, drastic changes arise within and between the host and in natura conditions.

One such stress is antibiotics. The widespread use of antibiotics to treat livestock for enhanced meat production as well as the rise of antibiotic-resistant bacterial strains in medical contexts lends the question practical importance. Genetic resistance may also have an important relationship with transient antibiotic
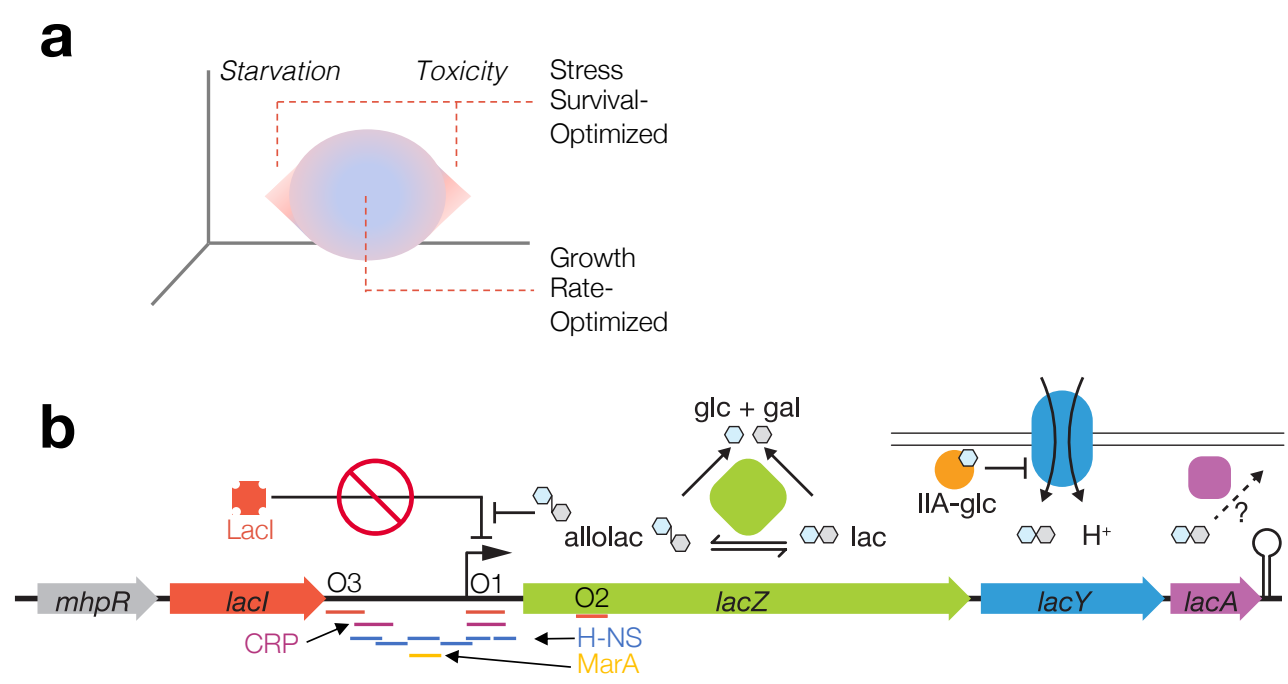

Figure 1. Fitness in a mesophilic microbe and the lac operon of Escherichia coli specifically. a. There is an envelope of survivable conditions in mesophilic bacteria. The volume labeled "Growth Rate-Optimized" denotes conditions to which the microbes are well-adapted for fast growth. In the peripheral volume, "Stress Survival-Optimized" (e.g., the stringent response and bet-hedging), the combination of environment and response improves colony survival but not growth rate. $\mathbf{b}$. The mechanism to perturb fitness in this study is titration of lactose as a sole carbon source in minimal media. Lactose processing involves intrinsic physiological costs and may cause downstream toxicity in certain conditions via the Leloir pathway (galactose processing; not shown). 
tolerance: persistence may allow resistance to evolve more quickly $(3,4)$, though this hypothesis has been contested. Multiple mechanisms induce persister formation (5-9), including starvation or loss of metabolic activity (10-14).

We previously demonstrated that excessively high or low lactose concentrations (as a sole carbon source) can predispose populations of bacteria derived from a strain of Escherichia coli, B REL606, to lowered death rates in antibiotics (15). Varying the concentration of lactose in a minimal medium drives a non-monotonic relationship with the exponential growth rate in culture, with a fast-growth plateau at intermediate concentrations (15). Lactose has established toxic effects on E. coli cultures, often attributed to membrane depolarization via excessive proton symport with lactose through the permease LacY, a member of the major facilitator superfamily of permeases (16-18). In B REL606, toxic lactose levels create a heterogeneous population dynamic with a chance of fast-growing cells to enter growth arrest, yet both starving and toxified cultures exhibit increased stress tolerance (15, 19; Fig. 2). Growth-arrested cells represent a persister-prone subpopulation in both conditions such that the toxified culture has the effect of a bet-hedging dynamic with average population growth rate sacrificed in favor of stress tolerance in a minority of the population. Does the global transcriptional program of stress responses have overall similarities between these conditions, or are key alternate pathways activated? The mechanisms for these conflicting stresses to attain a similar phenotype are unknown. 
We interrogated this system with the bulk (population-level) RNA-seq under the hypothesis that a common stress response is conserved between starvation and toxicity. While making use of bioinformatic, biochemical, and physiological data about specific mechanisms, we avoided presuming that any particular
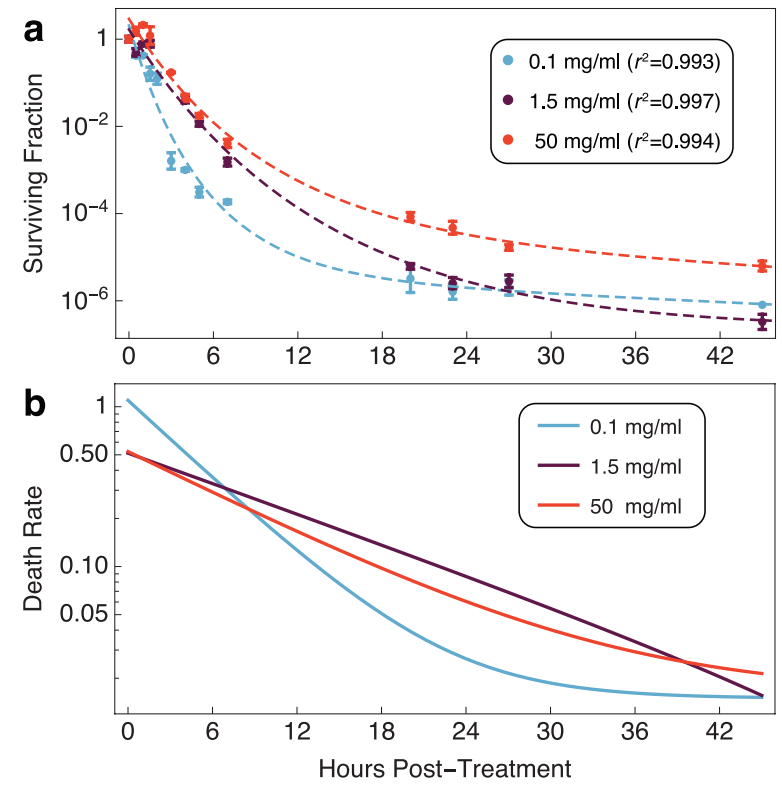

Figure 2. The killing rate of an E. coli $\mathrm{B}$ strain in ampicillin is lowest in starving and toxified culture conditions. a. Surviving fractions in low, intermediate, and high lactose conditions after ampicillin treatment $(100 \mathrm{mg} / \mathrm{ml})$ during mid-exponential phase (mean \pm standard deviation, $N=3$; final point in $1.5 \mathrm{mg} / \mathrm{ml}, N=$ 1). Data from (2) were fit to a mixed linear-exponential model $y=$ $a t+b e^{-g t}+c$ with $r^{2}$ as reported in the figure. b. Time derivative $-\frac{d y}{d t}$ of the statistical model parameterized for each fit in panel a shows a lowered killing rate for both starving and toxified cultures between approximately 7 and 40 hours post-treatment. Model fit parameters:

(dose): $(a, b, c, g)$

(0.1): $(-0.0149675,5.71624,-5.40263,0.189278)$

(1.5): $(0.00427562,7.13623,-6.91445,0.072367)$

(50): (-0.0161676, 4.99618, -4.53027, 0.101607) mechanism was at work beyond the proven phenomena arising in these culture conditions. We cultured E. coli in low, intermediate, and high concentrations of lactose minimal medium, grew them to mid-exponential phase, and harvested biomass from each culture for bulk RNA-seq. The resulting transcriptional profiles were subjected to differential expression analysis with the intermediate lactose concentration as the reference condition.

\section{$\underline{\text { 2. Results }}$}

\subsection{Slowed killing rate in starving and toxified E. coli cultures}

Re-analysis of our previously measured timecourse of exponential-phase E. coli 
treated with ampicillin demonstrates a lowered rate of death in starving and toxified cultures (Fig. 2). To confirm this, we fitted the data to a mixed linear-exponential statistical model in logarithmic coordinates on the $y$ axis: $y=a t+b e^{-g t}+c$. All three parameters were fit with low error $\left(r^{2}>0.99\right)$. Taking the time derivative of the statistical model revealed the estimated rate of killing for each culture condition (Fig. 2b): highest in non-stressful conditions. Thus, both the starving and toxified cultures are prone to produce higher levels of antibiotic tolerance than less stressful intermediate conditions.

\subsection{Differential gene expression analysis reveals growth-mediated shifts in lac operon expression, toxin-antitoxin responses, and global regulator responses}

To analyze gene expression profiles, we purified total RNA from early-mid-exponential cell culture in different lactose concentrations. We mapped sequencing reads to the reference genome E. coli B REL606 NC_012967.1 (20) with kallisto (21) and subsequently analyzed the count data using DESeq2 in R (22) with subsequent processing in Python. Setting the moderate lactose concentration $(2.5 \mathrm{mg} / \mathrm{ml})$ condition as the reference, we defined differentially expressed genes (DEGs) in starvation (lactose conc. $0.1 \mathrm{mg} / \mathrm{ml}$ ) and toxified (lactose conc. $50 \mathrm{mg} / \mathrm{ml}$ ) conditions as genes with an adjusted $p$-value (false detection rate; FDR) of below 0.05 and a $\log _{2}$ fold change (LFC) greater than 1 (Figure 3). 
a

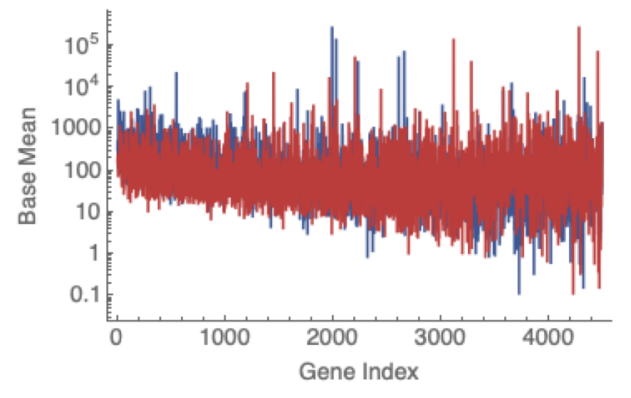

C

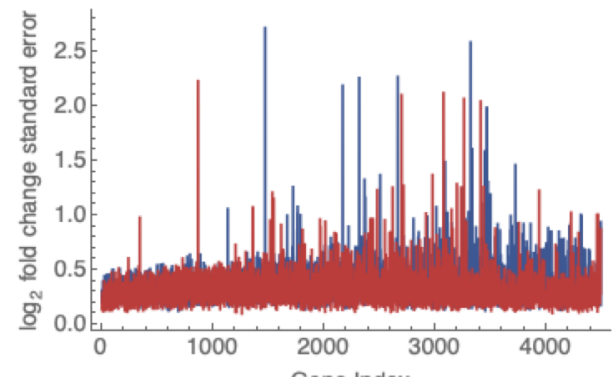

b
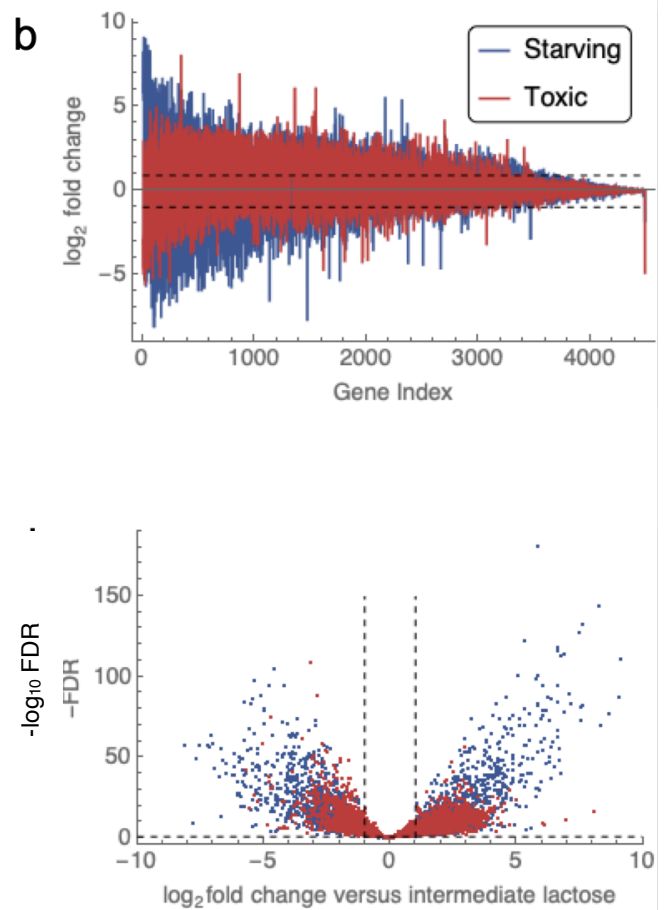

Figure 3. Comparison of differential expression profiles between starving and toxified cultures, both relative to a nominally lower-stress condition. a. Base mean number of reads. b. Mean fold change of each gene sorted by FDR from lowest to highest (Gene Index). Dashed lines indicate $>2$-fold change in expression compared to intermediate-lactose cultures. c. Standard error of the fold change mean between biological replicates. $\mathrm{N}=7$ biological replicates for starving cultures, 9 for toxified cultures, and 9 for intermediate lactose cultures. d. Volcano plot reveals the extent of differential expression. Dashed lines indicate thresholds for meeting the criterion for significant differential expression: $>2$-fold change and false detection rate $(\mathrm{FDR})<0.05$.

In Figure 3a, the base mean is the normalized mean expression level for each gene in all replicates in the culture condition. The standard errors from the shrunken $\log _{2}$ fold change to corresponding maximumlikelihood estimates are well controlled (Figure 3c). They aligned well for a proper size factor calculation. Overlaying the differential expression $\log _{2}$ fold change shows that the starving cultures had wider $\log _{2}$ fold changes, suggesting a more extensive regulon, and perhaps more severe stress, compared to toxified cultures. This result is consistent with our previous results (15) and the model shown in Figure 1, where cells have a higher death rate under low lactose compared to toxic lactose conditions. 
Out of 4490 genes in the genome, 1845 DEGs were upregulated and 1145 DEGs were downregulated in starvation, while 1755 DEGs were upregulated and 830 DEGs were downregulated in toxified cultures. Clustering of differentially expressed genes revealed that starving cells and toxified cultures have overlapping, but not identical, regulons (Figure 4a). Genes that were either upregulated or downregulated are colorcoded points in Figure 4b. Many regulated genes trend toward equal differential expression (near the $y=x$ line), but the data reiterate here the observation that starving cultures have a larger set of gene expression changes than toxified cultures ${ }^{1}$.
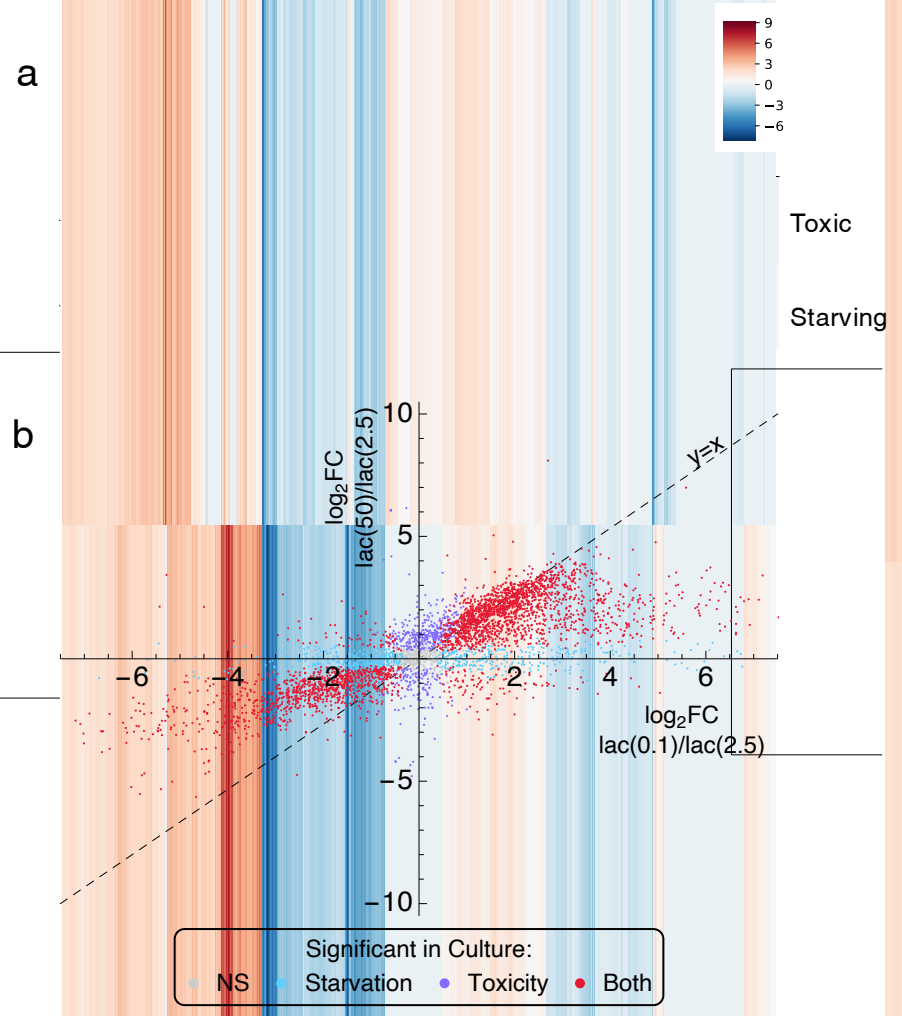

Figure 4. Fold change of genes in starving cultures versus toxified cultures relative to the intermediate baseline. a. DEGs clustering based on the $\log _{2}$ fold changes for each gene, where toxified cell profile behaves quite different from starved cells. b. Points are genes color-coded based on which conditions have significant fold change (FC). NS, non-significant.

${ }^{1}$ Practical constraints prevented our study from creating a distance metric for how quantitative changes in lactose correspond to quantitative changes in gene expression beyond the cases shown here. Interpretations are thus carefully 
Expression of the lac operon is a natural question in experiments where the quantity of lactose in cultures is varied. The E. coli strain used here lacks a functional lactose regulator (LacI), an intentional choice to disentangle the downstream consequences of lactose processing without the added complication of lac operon gene regulation. Because the lacI gene has a point mutation, detected transcripts encoding LacI were non-functional (Figure 5). Growth in lactose minimal medium requires lac operon expression in any case (Figure 1b). Any apparent differential expression of lac operon gene products is attributable to the following remaining factors (23): silencing by H-NS and MarA, activation by CRP-cAMP, $\sigma^{70}$-activated promoters, and effects on mRNA concentrations by differential loss from either growth or a shift in mRNA degradation. The particular strain we used also expresses a recombinant GFP constitutively, which we have previously exploited as an optical proxy for growth rate because slower-growing cells accumulate GFP and become brighter $(15,19)$.

Following the steps of lactose processing is informative to see the difference between molecular gene regulation and the consequences of fitness, growth, and selection on gene expression in culture. LacY is the lactose permease, transferring extracellular lactose across the inner membrane into the cytoplasm (Fig. 1b). The starved cells contain substantially increased expression of LacY mRNA, suggesting that surviving cells in the culture have increased lactose uptake. In toxified cultures, $l a c Y$ is not differentially expressed, suggesting relaxed selection for high lactose permease levels. The gene lac $Z$ encodes $\beta$-galactosidase, the catabolic enzyme that directly assimilates lactose into the metabolic network. lac $Z$ is downregulated in toxified cultures, which may reflect the fact that most cells in the toxified culture randomly avoided toxicity by lowered lactose assimilation. Galactose degradation (the Leloir pathway) is directly downstream of lactose degradation by $\beta$-galactosidase, and UDP-galactose and galactose-phosphate intermediates in the

limited to categorical comparisons between the culture states rather than quantitative shifts of gene expression from changes in lactose concentration. 
Leloir pathway can cause stress and reduce cell growth $(24,25)$. Differential expression of lac $A$ has unclear functional consequences and may simply reflect co-expression with lacZ and lacY from the operon.

We next explored differential expression of global regulators of growth rate: toxin-antitoxin systems (Fig. 5b) and transcriptional regulators (Fig. 5c). With gene annotation matching (see Methods), we found a total of 15 toxin-antitoxin (TA) modules existing in the B REL606 strain of E. coli. Among these TA modules, starving cultures exhibited activation of 6, including ygiT-mqsR, YhfG-Fic, Xre-HipA, yeeUV, ghoTS and hokE-lexA. Interestingly, ygiT-mqsR, yeeUV, and ghoTS are also upregulated in toxified cultures, while the other 3 TA systems show upregulated toxin genes. Knockouts of the global regulators in Fig. 5c result in at least a 10-fold decrease in persister formation (26). In starving cultures, 6 global regulators out of 9 are downregulated, including stress response regulator genes dnaKJ, DNA protection-related regulator genes hup $A B$, a folate-dependent enzyme inhibitor gene $y g f A$, and persister cell formation regulator gene $y i g B$. Though the recombination-related regulator genes $i h f A B$ are upregulated, suggesting a possible higher mutation rate, $d k s A$ is also upregulated; the latter's product can promote DNA recombination repair (27). The product of $d k s A$ is also an rRNA repressor that mediates stress responses and inhibits DnaK. Thus, we observe a pattern of gene regulation with counterbalancing effects that may be consistent with phenotypic decisions being made post-translationally. In toxified cultures, ihfB and the chemotaxis signaling genes che $Z$ and $c h e Y$ were upregulated. 
a
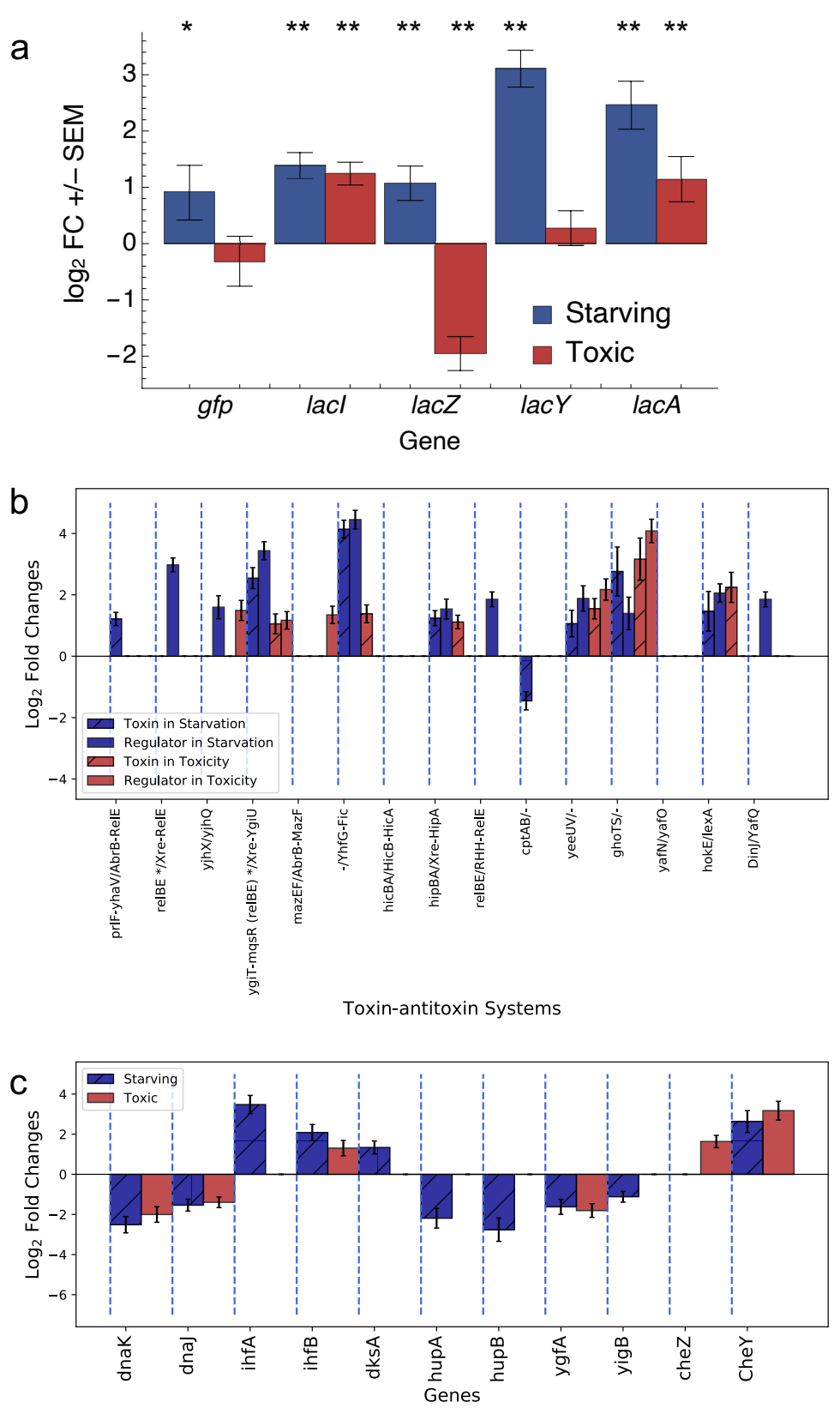

Figure 5. Differential expression $\log _{2}$ fold changes of reference genes in starving and toxified cultures establishes a baseline reference for persister-prone conditions. a. lactose operon activities. In this strain, the lacI gene is present but non-functional because of a mutation. As a result, the lac operon is expressed constitutively, as is the inserted $g f p$ gene. FC, fold change. SEM, standard error of the mean. $\mathrm{N}=7$ for starving cultures, 8 for toxified cultures, and 8 for intermediate lactose cultures. **: FDR $<0.001$; *: FDR $<0.05$. b. Toxin-antitoxin systems. c. Global regulator genes and chemotaxis signal transduction related genes (cheZ and cheY). 


\subsection{Stress responses regulated by sigma factors}

Transcription initiation for E. coli promoters requires sigma $(\sigma)$ factors, subunits of RNA polymerase (RNAP) (28), making them global regulators of responsiveness to the environment. Individual promoters typically respond to specific $\sigma$ factors. Six $\sigma$ factors are known in E. coli B REL606. $\sigma^{28}$ (RpoF/FliA), the flagellar synthesis sigma factor in E. coli strain K-12 MG1655, is missing in REL606 and $\sigma^{19}$ (FecI), the ferric citrate sigma factor regulating iron transport and metabolism, is present but does not have any annotated gene regulatory roles in RegulonDB (29). To understand how $\sigma$ factors regulate cellular responses to environmental stimuli, we explored their differential expression between lactose concentrations and that of their regulated genes as $\log _{2}$ fold changes (LFC2).
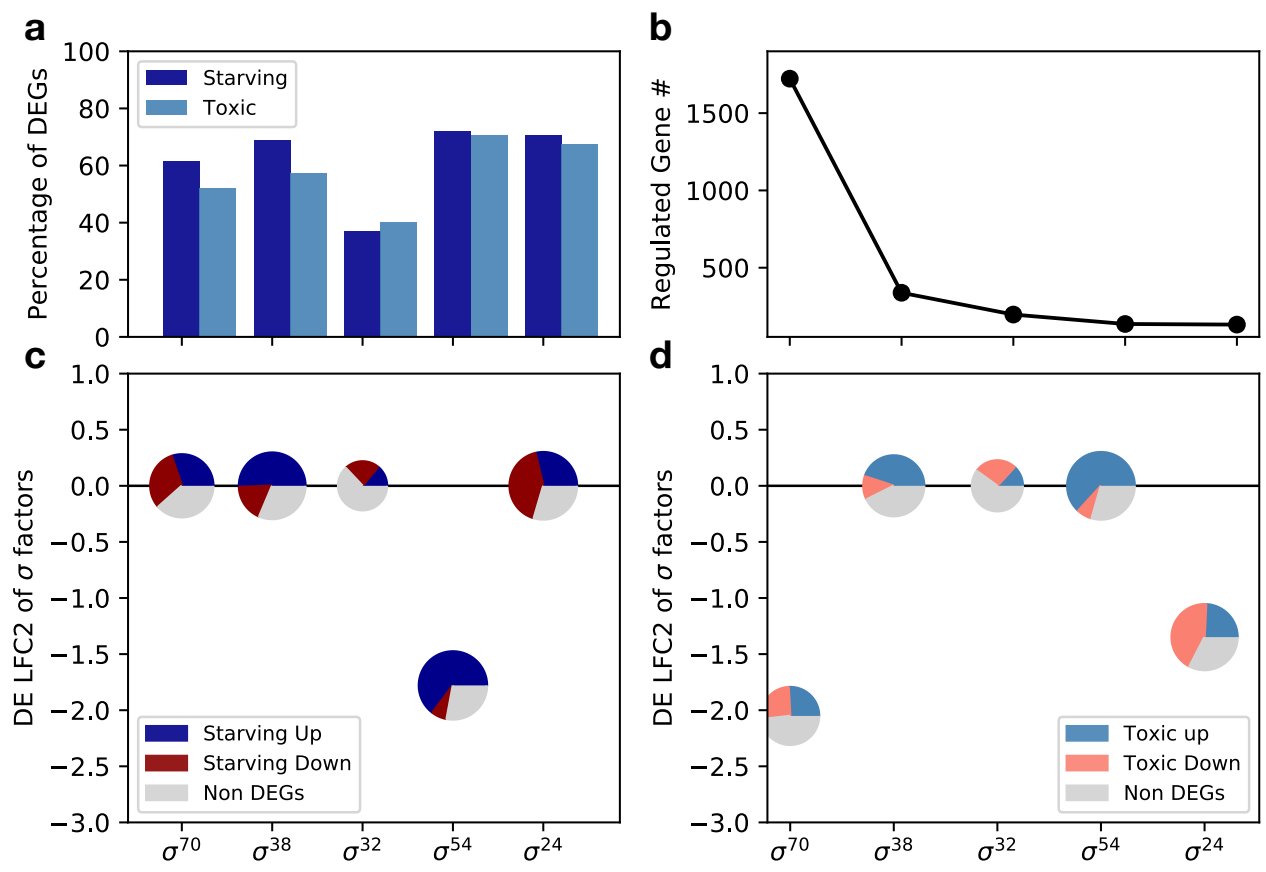

Figure 6. Regulation of $\sigma$ factors differ in response to starvation and toxification. a. Percentage of differentially expressed genes (DEGs) in each $\sigma$ factor regulon. b. The number (\#) of genes annotated to be regulated by each $\sigma$ factor. c, $\mathbf{d}$. Differential expression ( $\log _{2}$ fold change) of the $\sigma$ factors and their regulons in c. starving and $\mathbf{d}$. toxified cultures. The size of the pie chart reflects the DEG percentage regulated by each sigma factor. $\mathrm{LFC} 2, \log _{2}$ fold change.

Our results show a significant decrease in $\sigma^{70}(r p o D)$ in toxified, but not starving, cultures (Fig. $\left.6 \mathrm{c}, \mathrm{d}\right)$. This $\sigma$ factor initiates transcription in a set of approximately 1723 genes involving cell proliferation-related 
behavior such as substrate uptake, DNA replication, membrane synthesis, and ribosome production (23). About half of the genes initiated by $\sigma^{70}$ were downregulated in both toxified and starving conditions, suggesting an overlapping regulon between the stress responses in starved and toxified cultures.

$\sigma^{38}$ (rpoS), the sigma factor associated with the stringent response, does not appear to be differentially expressed on average in starving or toxified cultures, yet a plurality of genes regulated by $\sigma^{38}$ is upregulated in both conditions as compared to growth-optimized lactose concentrations. This observation is consistent with $\sigma^{38}$ regulation arising from sigma factor competition, especially in toxified cultures. The ratio of $\sigma^{70}$ to $\sigma^{38}$ in toxified cultures is consistent with this model as well. (p)ppGpp is involved in both production and activity of $\sigma^{38}(30)$. The (p)ppGpp synthases, relA and spoT, are downregulated in both starving and toxified cultures. This is not necessarily inconsistent with the presence of the stringent response, as (p)ppGpp is known to exhibit a transient increase early in the stringent response, possibly before we sampled the cultures for RNA-seq (31).

$\sigma^{54}(\mathrm{rpoN})$ stimulates transcription initiation in 136 genes involving nutrient limitation such as nitrogen assimilation, substrate-specific transport systems, and utilization of alternative carbon and energy sources. Most genes in the $\sigma^{54}$ regulon are downregulated in both starving and toxified cultures, despite $\sigma^{54}$ itself being downregulated or not significantly differentially expressed in starving and toxified cultures. The bestcharacterized mechanism for $\sigma^{54}$ interactions with $\sigma^{38}$ is through the glutamate-dependent acid resistance (GDAR) system ( $\mathrm{gadE}, \mathrm{gadA}, \operatorname{gadBC}$ ) (32). $\sigma^{54}$ is described as a repressor for GDAR system, while $\sigma^{38}$ is annotated as an activator.

$\sigma^{24}$, driving responses to heat shock and other stresses on the membrane and periplasmic proteins, is downregulated on average in toxified cultures but is not significantly regulated in starvation here. $\sigma^{24}$ is required for transcription of $\operatorname{deg} P$, a gene coding for a protease that degrades abnormal proteins in the periplasm (33). Downregulation of $\sigma^{24}$ may result in less DegP protease, causing accumulation of DegP targets. Such accumulation is associated with increased membrane resilience, which is relevant because one 
of the factors thought to stabilize this strain of E. coli in toxified cultures is resistance to osmotic stress caused by excessive lactose import (see Discussion).

In all, downregulation of $\sigma^{70}$ may drive a stimulon associated with $\sigma^{38}$ - and $\sigma^{54}$-compatible promoters. The majority of genes regulated by $\sigma^{38}$ and $\sigma^{54}$ encode stress responses in both nutrient scarcity and conditions of over-abundance. However, sigma factor $\log _{2}$ fold changes are not always consistent with the dominant trend of gene differential expression, which we interpret to mean that post-translational interactions drive part of the response and that additional regulatory factors play a role in the responses of $E$. coli to starving and toxified conditions.

As starvation and toxicity are both intertwined with metabolism, we performed metabolic pathway gene set enrichment analysis in peripheral (Section 2.4) and central (Section 2.5) metabolism. We used the normalized enrichment score (NES), a statistic that reflects the degree that a pathway is overrepresented at the top or bottom of a ranked list of genes (Methods Section 4.5). An overview of our pathway enrichment analysis is presented in Figure S2.

\subsection{Peripheral metabolic pathway gene set enrichment analysis}

\subsubsection{Pathway regulatory similarities between starving and toxified cultures}

Gene set enrichment analysis calculates trends for defined gene sets. The similarity of pathway regulation was calculated using rank correlations (Spearman's $\rho$ ) with differential gene expression profiles (see Methods Section 4.5.1).

Figure S3 shows the correlation between pathway regulation in starvation and toxicity. Each node in Figure S3 represents a pathway, with a total of 362 pathways annotated in E. coli B REL606. Nodes are connected by metabolite edges as annotated in EcoCyc. We found that most metabolic pathways are either similarly regulated or have no correlation between treatments. We observed conserved regulatory pathways for persister-prone phenotypes, including central metabolic pathways such as the pentose phosphate pathway, chorismate biosynthesis I, glycolysis I, and the superpathway of glyoxylate bypass and TCA. Glycolysis is the hub node for the pathway network with similarly regulated pathways linking to glycolysis with 
degree 1 node distances. Statistically significant oppositely regulated pathways are rare. The only oppositely regulated pathway with statistical significance is tetrahydrofolate $\left(\mathrm{FH}_{4}\right)$ biosynthesis, which is upregulated in starvation but downregulated in toxicity. $\mathrm{FH}_{4}$ biosynthesis produces vitamin $\mathrm{B} 9$ (folic acid), a cofactor leading to the biosynthesis of methionine, purines, thymidylate and pantothenate. 


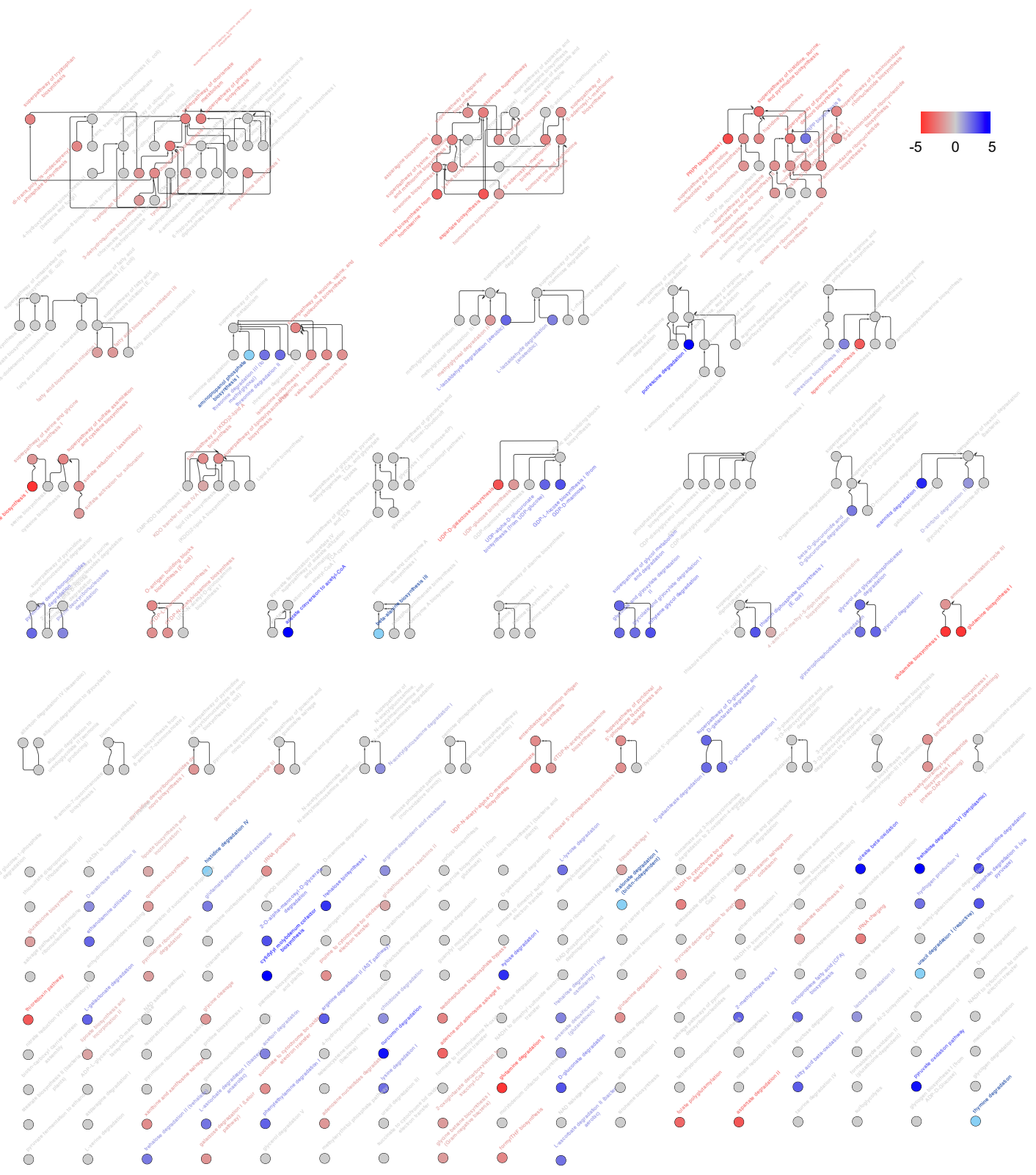

Figure 7a. Pathway enrichment score graph representation for pathway ontology in starvation condition. The upregulated pathways are shown in blue, and downregulated pathways are shown in red. The pathway ontology annotation is from EcoCyc The pathway ontology annotation is from EcoCyc (1). 
bioRxiv preprint doi: https://doi.org/10.1101/2021.12.17.473201; this version posted December 18, 2021. The copyright holder for this preprint (which was not certified by peer review) is the author/funder, who has granted bioRxiv a license to display the preprint in perpetuity. It is made available under aCC-BY 4.0 International license.
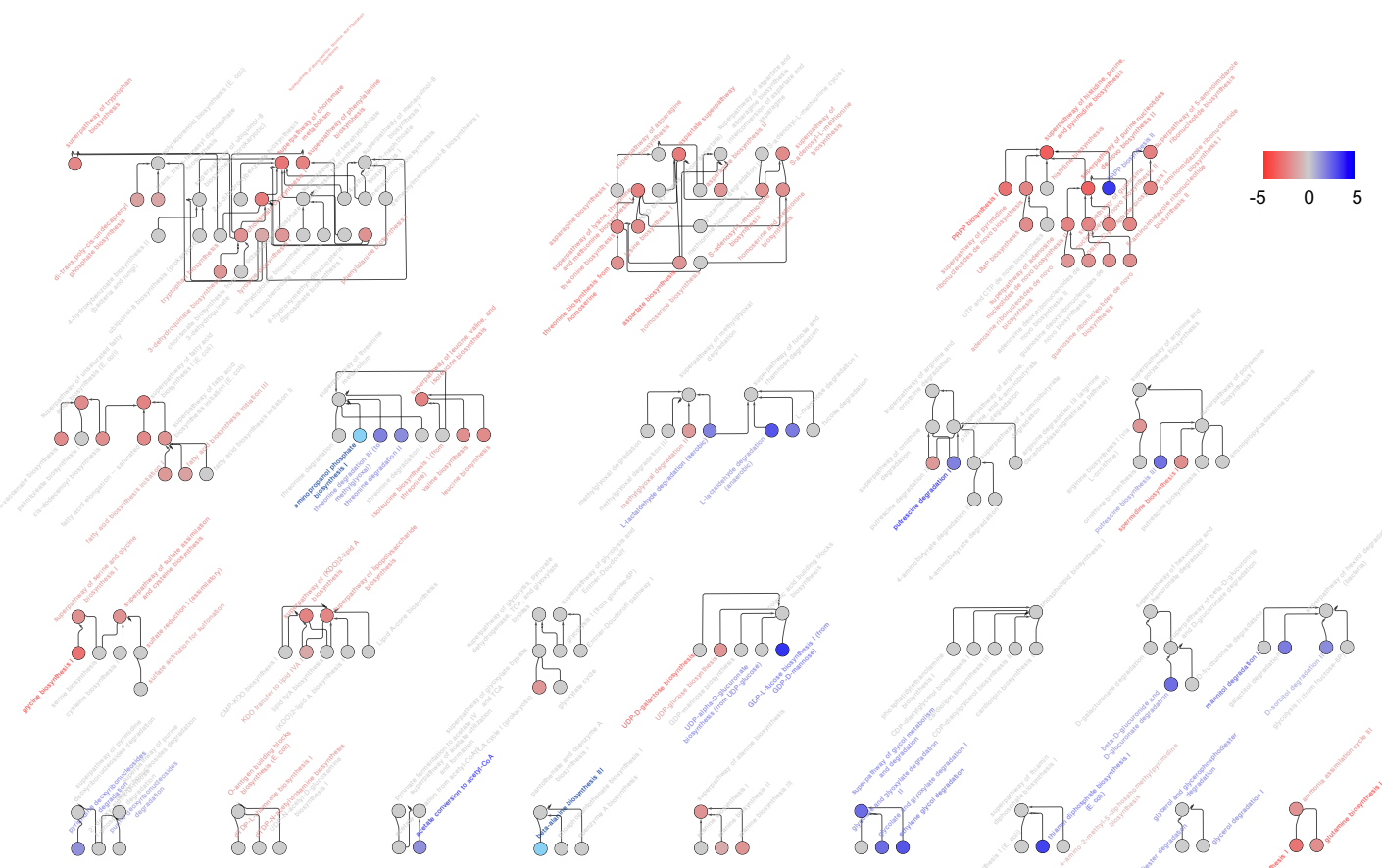


\subsubsection{Common enriched pathways in persister-prone phenotypes}

Among 362 enriched pathways, 44 were upregulated in starvation and toxification, 69 were downregulated in starvation and toxification, 14 were uniquely upregulated in starvation, 31 pathways were uniquely downregulated in starvation, 12 pathways were uniquely upregulated in toxification, and 25 pathways were uniquely downregulated in toxification. Detailed pathway enrichment analysis results can be found in Supplementary Tables S1-S6. Figure 7 shows the pathway hierarchy structure based on EcoCyc annotations. The directed edges point to the parent pathway which is often consisted of multiple pathways to form superpathways. In Figure 7 we mapped the normalized enrichment score calculated with FGSEA (34) onto the pathway hierarchy graph. The result is many clustered enriched pathways. The top 3 clusters in Figure 7 are (1) the superpathway of chorismate metabolism, (2) amino acid biosynthesis, and (3) the superpathway of histidine, purine, and pyrimidine biosynthesis.

Chorismate is the principal precursor for the aromatic amino acids, such as tryptophan, tyrosine, and phenylalanine (35). Downregulation of chorismate biosynthesis can introduce aromatic amino acid starvation (this may occur in both toxication and starvation according to the enrichment profile). Menaquinol-8, ubiquinol-8, tetrahydrofolate biosynthesis, and enterobactin biosynthesis are not differentially regulated compared to the cultures with intermediate lactose concentration (chorismate metabolism provides essential compounds for those pathways). The quinone pool is essential for E. coli adapting to different oxidative conditions and maintaining proper redox- and phosphoryl-transfer reactions to form the core of cellular energetics (36). Biosynthesis of ubiquinone is reported to accumulate pathway intermediates $(37,38)$ with the effect of improving osmotic stress-tolerance.

We found that 17 out of 20 amino acid biosynthesis pathways are downregulated in persister-prone phenotypes accompanying upregulated amino acid degradation pathways (Table S2.). Alanine and arginine biosynthesis are uniquely downregulated in toxification, while asparagine is uniquely downregulated in starvation, implying lower NAD synthesis (39) and likely resulting in lower energy levels. Amino acid starvation can lead to accumulation of uncharged tRNAs that enter the ribosomal A site, halting translation 
(40). We observe downregulated tRNA charging in both toxicity and starvation. The pyrimidine, purine and pyridine nucleotide synthesis-related pathways are downregulated in both starvation and toxicity except for phosphoribosylpyrophosphate (PRPP) biosynthesis II, which provides PRPP as a pivotal metabolic precursor to pyrimidine, purine, and pyridine nucleotide synthesis. Other downregulated pathways include sulfate assimilation downstream of cysteine biosynthesis, lipid A, lipopolysaccharide (LPS) and peptidoglycan biosynthesis, spermidine biosynthesis, UDP-glucose biosynthesis, and cytochrome $b_{0}$ oxidase electron transfer pathways from proline succinate.

Upregulated pathways have a sparser network structure (Table S1). Among 44 commonly upregulated pathways, 30 are degradation pathways targeting amino acids, other carbon sources, and electron transferrelated metabolites, such as L-ascorbate (vitamin C) and putrescine. Broadly upregulated nutrient assimilation pathways reflect supervening carbon source uptake and balancing energetic electron transfer. Other upregulated pathways enhance cellular fitness through energy metabolism, overflow metabolism, and membrane component regulation. In both persister-prone conditions of this study, the pyruvate oxidation pathway is upregulated; this pathway generates the transmembrane potential for constructing respiratory chains consisting of pyruvate oxidase, ubiquinone- 8 , and the cytochrome $b d$ complex (41). Thiamine diphosphate biosynthesis I produces cofactor vitamin B1, which plays a fundamental role in energy metabolism. Trehalose pathway upregulation affects the osmotic stress response, notably present in both stress conditions. In response to acetate and osmotic pressure, the arsenate efflux pump, GDAR system, and aerobic utilization of acetate are upregulated. GDP-L-fucose biosynthesis I produces LPS components in the membrane, and membrane structure may be further stabilized by enrichment in putrescine biosynthesis III, which is the precursor for spermidine biosynthesis.

\subsubsection{Uniquely enriched pathways in starvation}

Pathways uniquely upregulated in starvation (Table S3) include nutrient assimilation from metabolites mannitol, D-arabinose, acetoin, glycerol, glycolate, glyoxylate, trehalose, and fatty acids. The argininedependent acid resistance pathway was also observed. 
Though downregulation (Table S4) of the Leloir pathway may be beneficial to reduce UDP-glucoseinduced toxification, it may also limit production of $\alpha$-D-glucopyranose-1-phosphate, a precursor for synthesis of the outer membrane LPS component O-antigen. Despite O-antigen synthesis precursor UDP- $\alpha$-Dglucuronate biosynthesis being upregulated, biosynthesis of O-antigen building blocks from precursors including $\alpha$-D-glucopyranose-1-phosphate and sugars L-rhamnose, and dTDP- $N$-acetylyiosamine are specifically downregulated in starvation.

Downregulation of glutathione biosynthesis and redox reaction III may play a role in redox balance and defense against reactive oxygen species.

Several other pathways uniquely downregulated in starvation suggest a trend toward energy conservation: downregulation of lipoate metabolism, the pentose phosphate bypass, sedoheptulose bisphosphate metabolism, thiamine precursor biosynthesis, nucleotide precursor biosynthesis, and several acyl-CoA derivatives.

Finally, asparagine biosynthesis pathways are uniquely downregulated in starvation, with unclear functional significance.

\subsubsection{Pathways specifically enriched in toxicity (Table S5)}

Two pathways forming the E. coli anaerobic respiratory chain are upregulated: the formate-to-dimethyl sulfoxide electron transfer pathway and nitrate reduction III, implying increased proton-motive force across the cytoplasmic membrane (42-45). We observed upregulation of taurine degradation IV, which provides alternative sulfur under sulfate starvation induced by cysteine starvation (we note that our culture conditions are similar to those often used with this E. coli strain in the LTEE: Davis minimal medium containing supplemented lactose and thiamine (46) without amino acid supplementation). Several sugar degradation pathways are uniquely upregulated in toxicity, suggesting a possible carbon source alternative for $N$-acetylgalactosamine (GalNAc), D-galactosamine (GalN), D-malate, L-rhamnose, and galactitol. Other enriched pathways are mostly fermentation metabolic pathways. 
The superpathway of fatty acid biosynthesis initiation is uniquely downregulated in toxified conditions (Table S6). Related pathways such as fatty acid elongation, palmitoleate biosynthesis, and cis-vaccenate biosynthesis are also uniquely downregulated. Fatty acids are key building blocks for phospholipid components of cell membranes and are determinants of intracellular communication where palmitoleate is a common unsaturated fatty acid. Farnesyl pyrophosphate (FPP) biosynthesis is downregulated, possibly implying less membrane attachment in posttranslational modifications.

\subsection{Gene set enrichment analysis of central metabolism}

To complete the analysis of regulated metabolic pathways in starvation and toxicity, we mapped differential expression to central metabolism (Fig. 9). As the culture conditions in this study demand that the initial entry to central metabolism occurs via lactose degradation, we define central metabolism herein to be composed of the lactose degradation pathway, pentose phosphate pathway, glycolysis, Entner-Doudoroff shunt, TCA cycle, and the glyoxylate bypass. As galactose is a direct product of lactose degradation, we included the Leloir pathway (galactose degradation I) as well.

In starvation, the glycolysis pathway is mostly downregulated except for one gene encoding a phosphate transfer reaction. Components of glycolysis are more consistently upregulated in toxicity. The EntnerDoudoroff shunt linking glycolysis to the TCA cycle is regulated oppositely between starving and toxified cultures. The shunt is upregulated in starvation, possibly providing paths to alternative metabolites. Though the TCA cycle is largely downregulated in both conditions, the glyoxylate cycle is upregulated by various degrees in both starvation and toxicity. The glyoxylate cycle is a bypass for the TCA cycle to skip steps that remove $\mathrm{CO}_{2}$, thus conserving carbon intermediates during growth (47-49). The pathway is repressed during growth on glucose, and induced by growth on acetate, the byproduct of overflow metabolism. 

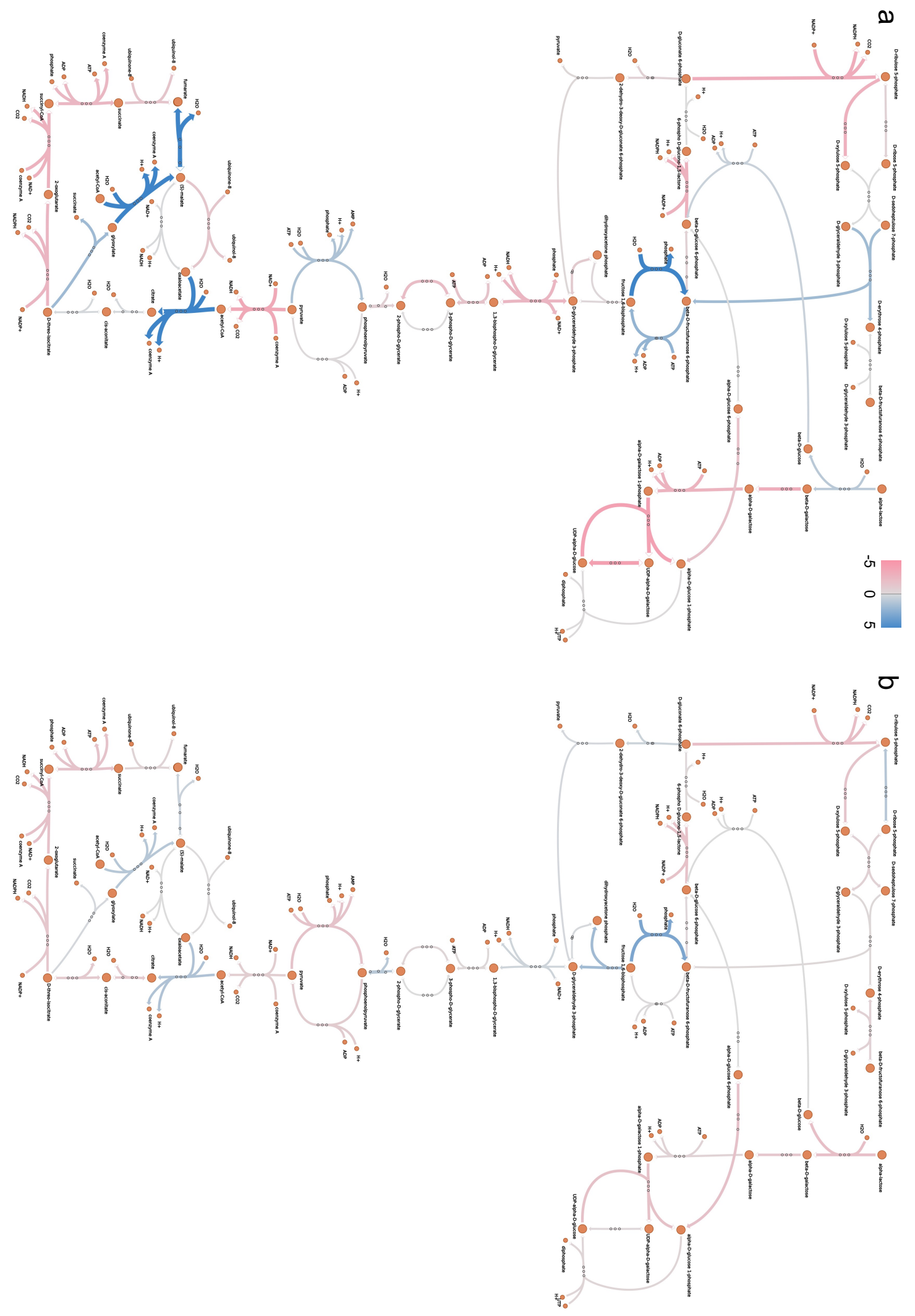

Figure 9. Differential expression ( $\log _{2}$ fold changes) of genes encoding central metabolism in a starving and $\mathbf{b}$ toxified cultures. 


\section{$\underline{\text { 3. Discussion }}$}

Variation in fitness-relevant environmental properties affects cellular gene expression patterns in quantitative and qualitative ways. Our previous demonstration that an excess of a required nutrient drives the formation of antibiotic tolerance (15) provided an opportunity to re-evaluate the nature of integrated microbial stress responses. This phenomenon appears to arise from the robust nature of the cell wall in B strains of E. coli, which permits survival in adverse osmotic conditions (50). We were specifically able to enrich antibiotic-tolerant cells in conditions both below and in excess of optimal concentrations for lactose as the sole carbon source (Fig. 1). We created such conditions in batch culture to test hypotheses about the nature of antibiotic tolerance in E. coli: what kind of signal may predispose cells to stress tolerance, and do conditions that could be described as "opposite" of each other from osmotic, nutrient concentration, and media toxicity perspectives induce similar or largely different responses?

We conceptualized analysis of the stress response by analogy to a statistical model, with linearly independent (normalized) stress response components $\xi_{i}$ and interactions $\xi_{i j}$ between components $\xi_{i}$ and $\xi_{j}$ such that a given response $i$ is independent from $j$ if $\xi_{i j}=0$. The integrated response can then be characterized by $\Xi=\sum_{i} \xi_{i}+\sum_{i \neq j} \xi_{i j}$ (eliding coefficients because we assume normalization between the components). The integrated response $\Xi$ is a high-dimensional vector describing the phenotype. Independence between components may arise in some contexts and not others - we did not presume to comprehensively describe this space in our study, but rather to sample from it for exploration of the specific nature of stress responses. Nonzero interaction terms may arise from several sources, including pleiotropic effects (e.g., temperature or growth rate), co-expression (operon membership, transcriptional co-regulation, etc), and catalysis or synthesis of metabolites with broad effects (amino acids, nucleotides, tRNAs, etc).

Single cell dynamics play an important role in physiology and have a strong effect on lactose-toxified cultures. In the E. coli strain used in this study, a threshold drives toxicity to arrest growth in a subset of cells while subthreshold cells maintain growth. Thus, the results presented here represent an average across the subthreshold growing cells and the growth-arrested toxified subpopulation. The subthreshold 
subpopulation comprises approximately 10 percent of the entire population (15). This quantity arises from exponential growth of sub-threshold cells causing them to quickly overtake the population.

We exploited extensive mechanistic knowledge about the direct effects of pathways to interpret transcriptional signatures. Targeted experiments to further test other aspects of responses, such as post-translational effects, are beyond the scope of this study. Our results recapitulated previous interpretations of pathway analysis in stress but added crucial new results that broaden some, and narrow other, key interpretations. This study focused on the nature of the average gene expression in cultures known to be enriched for persister cells, but with no specific selection for them. In a following study, we will present an analysis of persister cells in the starving and toxified conditions that survived antibiotic treatment.

\subsection{Lactose toxicity-induced persistence may arise via a combination of overflow metabolism and}

\section{Leloir pathway intermediates}

One hypothesis for non-starving persistence is that metabolic toxicity is induced by critical proteomic concentrations. Galactose degradation I (the Leloir pathway) is directly downstream of lactose degradation by $\beta$-galactosidase and may accumulate UDP-galactose and galactose-phosphate intermediates causing stress and loss of growth. With high metabolic rates, E. coli (and virtually every other species) undergoes a metabolic shift from primarily aerobic metabolism to incomplete oxidation of metabolites, including ATP synthesis (51). The cause seems to be linked to proteomic optimization, as anaerobic ATP synthesis requires a smaller fraction of the proteome to synthesize an equivalent amount of ATP at the cost of more sugar (52). The smaller proteome allows for higher growth rates due to the reduced size of the necessary metabolome, allowing more transcriptional/translational machinery to be devoted to ribosome synthesis $(52,53)$.

We found that toxic culture conditions that produce persister cells have apparent utilization of the Entner-Doudoroff shunt, which connects pyruvate to phosphoenolpyruvate, thus linking to the glyoxylate cycle and downregulation of the enzymes responsible for oxaloacetate and acetyl-CoA entering the citric acid cycle, consistent with cells undergoing overflow metabolism. As the only carbon source initially present in the medium is lactose, GalE fluctuation may lead to UDP-Galactose toxicity (24), and indeed, galE is 
downregulated in high-lactose antibiotic-tolerant cells, but not significantly differentially expressed in untreated cultures.

\subsection{Different phenotypes may arise from sigma factor competition}

Regulation of stress responses in bacteria is generally considered to be robust to a variety of conditions. Despite being exposed to opposite stresses, we showed that differential expression of genes in starvation and toxicity is positively correlated. This may be due to leaky expression of genes in the different loci on the genome or generalized stress responses. As expected, regulated differentially expressed genes have wider fold change distributions compared to constitutively expressed genes and more genes are regulated in starvation than toxicity. We found that the global proliferation regulator $\sigma^{70}$ is downregulated in toxification, potentially reducing lac operon expression independently of LacI. As genes regulated by $\sigma^{38}$ are mostly upregulated in starving and toxified cultures, our results are consistent with the sigma factor balance leaning toward $\sigma^{38}$. The nutrient limitation-responsive sigma factor $\sigma^{54}$ is downregulated in starving cells, aiding glutamate-dependent acid resistance (GDAR). In toxified conditions, downregulation of $\sigma^{70}$ is drastic, moving the sigma factor competition balance towards $\sigma^{38}$. Though $\sigma^{54}$ is not downregulated, GDAR is again upregulated in toxified cells. Thus, nutrient-poor and nutrient-rich conditions both stress the cells with clear regulatory responses that overlap.

\subsection{Non-transcriptional and undetected factors at play in stress-responsive gene expression}

Survivorship bias, as opposed to targeted transcriptional regulation, may play a role in the observed transcriptome profiles obtained from stressed cells. Noisy gene expression dynamics creates a distribution of cell states, including some in sub-optimal transcriptional states. With exponential population growth, fitter cells quickly overtake the population and dominate the measured transcriptional signal. Furthermore, it was impractical to examine every possible transcriptional function. Some that we did not emphasize, such as prophage induction, may play an uncharcterized role in distinguishing responses to divergent stresses. Thus, studies of subpopulations and deeper targeted analysis may further clarify the overall similarities between divergent stresses. 


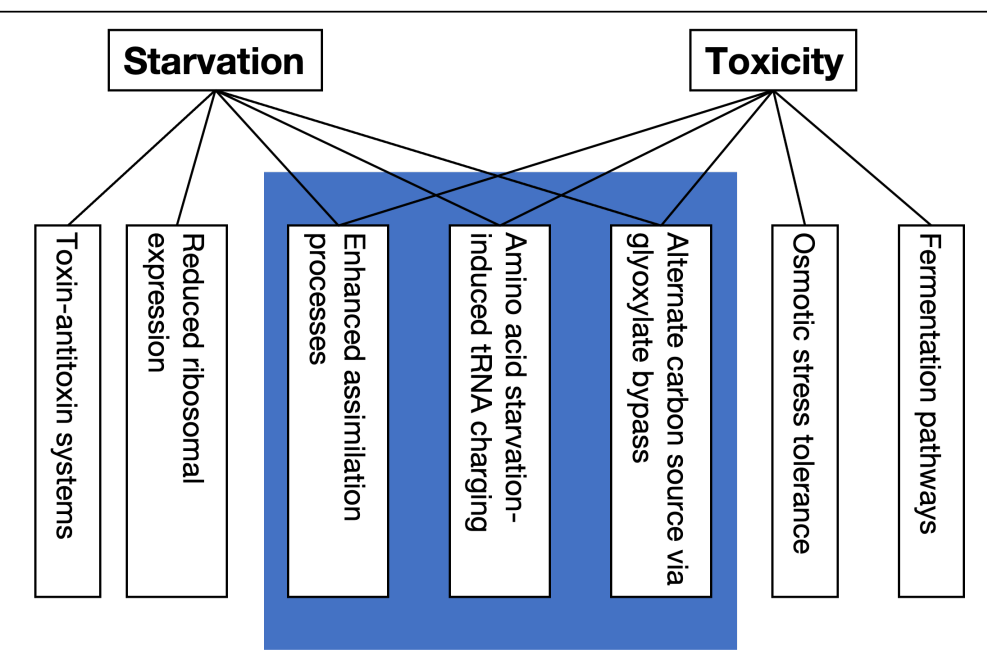

Figure 10. Overlapping and condition-specific stimulons in divergent stress responses of an E. coli strain.

\subsection{Summary}

The relationship between bacterial responses to divergent stresses contains four primary components: (i-ii) specific responses to each of the two stresses, (iii) a common stress-responsive regulon, and (iv) noise or functionally irrelevant responses. Overlapping responses include transcripts relating to nutrient assimilation, tRNA charging, and utilization of the glyoxylate bypass while condition-specific responses make sense in terms of unique properties of the stress in question (Fig. 10). 


\section{Materials and Methods}

\subsection{Persister Enriched RNA-Seq Experiments}

E. coli B REL606 lacI $I^{-}$transformed with Tn7::PlacO1GFP(KanR) was inoculated in LB medium from a $-80^{\circ} \mathrm{C}$ bacterial stock and grown for 16 hours in a $37^{\circ} \mathrm{C}$ shaking incubator. The LB culture was then resuspended (1:1000) into 5mL of Davis Minimal medium (DM; Difco) supplemented with thiamine and one of three lactose concentrations $(0.1 \mathrm{mg} / \mathrm{mL}, 2.5 \mathrm{mg} / \mathrm{mL}$, and $50 \mathrm{mg} / \mathrm{mL})$. The cultures were allowed to acclimatize for 24 hours before being resuspended (1:1000) into $5 \mathrm{~mL}$ of the same Davis Minimal medium and lactose concentration. Cultures were grown long enough to provide enough biomass for RNA-seq after antibiotic treatment ( 8 hours in $2.5 \mathrm{mg} / \mathrm{mL}$ lactose, 10 hours in $50 \mathrm{mg} / \mathrm{mL}$ lactose, and 12 hours in 0.1 $\mathrm{mg} / \mathrm{mL}$ lactose). After the initial growth phase, $1.5 \mathrm{~mL}$ cell culture aliquots were subjected to RNA isolation according to the following procedure.

Cell cultures were pelleted in a microcentrifuge (10,000 G for 2 minutes), washed in PBS buffer twice, resuspended in $500 \mu \mathrm{L}$ of RNA-Later (ThermoFisher) and stored in at $-20^{\circ} \mathrm{C}$ for up to one week. RNA isolation was performed using Direct-Zol (Zymo) and TRIzol reagent (ThermoFisher) and stored in a $-80^{\circ} \mathrm{C}$ freezer overnight. Isolated RNA was ribo-depleted using RiboZero (Illumina) with ethanol washing to precipitate the RNA. Library preparation was completed using NEBNext Ultra II Directional RNA Library Prep Kit for Illumina (New England Biolabs) and sequenced using MiSeq v3 Paired End 150 bp (Illumina).

\subsection{RNA-seq sequence alignment and genome annotation with Ecocyc and RegulonDB}

RNA transcript quantification was performed using kallisto (21) with reference genome NC_012967.1 (20) and 10 bootstrap samples. Functional interpretations used Ecocyc (Ver. 23.1) (54) and RegulonDB (55). Lacking extensive annotation of gene regulation in REL606, we used the K-12 MG1655 strain annotation based on gene names and gene product similarities.

\subsection{Differential Expression Analysis}

We used R package DESeq2 (56) for gene differential expression analysis. The RNA transcription quantification data were first clustered to isolate outlier replicates using principal component analysis 
(PCA) (Figure S2). Two samples with a high number of missing transcripts were dropped from subsequent analysis. To confirm reproducible outcomes of sample treatment, hierarchical clustering using the Wald significance test was performed on all samples; sample treatment was retrieved perfectly (Figure S1).

The DESeq2 pipeline includes size factor estimation, dispersion estimation, and DEG tests. Low-count RNA quantifications are noisy and may decrease the sensitivity of DEGs detection (57). Size factors were calculated with a subset of control genes: non-regulated genes according to RegulonDB (55) with expression higher than a threshold (10) across all replicates. Setting transcriptome quantification from the moderate lactose condition, we applied the adaptive-T prior shrinkage estimator "apeglm" and used Wald significance tests for detecting DEGs and obtaining the $\log _{2}$ fold changes (LFC2).

\subsection{Metabolic pathway enrichment analysis}

\subsubsection{Enrichment analysis by FGSEA}

At the time of analysis, there were 368 pathways in EcoCyc for B REL606. 6 pathways that are not apparently regulated by gene products were discarded. Pathway enrichment was analyzed using FGSEA (58). Differentially expressed genes were pre-ranked by their $\log _{2}$ fold change. Pathway gene sets were defined with reference to the EcoCyc database. The pre-ranked gene data and pathway gene sets were then processed by the fgseaMultilevel function to obtain final results. Minimum gene set size was set to 3 with 200 bootstrap replicates. The threshold for pathway significance was 0.05 .

Pathways in Figure 7 are linked by key metabolites and their flow direction. The pathway ontology in Figure 7 is annotated in the Ecocyc database. The pathway link and pathway ontology was extracted from EcoCyc and visualized with Cytoscape (59).

\subsubsection{Pathway regulatory mechanism similarity}

To calculate the similarity between pathway regulation in different conditions, we used Spearman's $\rho$ rank correlation between the differential expression profile for each pathway. The similarity score for cases where all gene enrichment in a pathway are of the same direction is set to 1 .

Metabolic pathway visualization used the Python package Escher (60). 


\section{Acknowledgments}

We thank Jaden Anderson, Jimmy Budiardjo, Hung Do, Susan Egan, Chad Highfill, Erik Lundquist, Jacqueline J. Stevens, and Pinakin R. Sukthankar for valuable discussions and assistance. This project was supported by Institutional Development Awards (IDeA) from the National Institute of General Medical Sciences of the National Institutes of Health under grant numbers P20GM103418 and P20GM103638. The content is solely the responsibility of the authors and does not necessarily represent the official views of the National Institute of General Medical Sciences or the National Institutes of Health. Research reported in this publication was also made possible in part by the services of the KU Genome Sequencing Core. This core lab is supported by the National Institute of General Medical Sciences (NIGMS) of the National Institutes of Health under award number P20GM103638. 


\section{References}

1. Keseler IM, Mackie A, Santos-Zavaleta A, Billington R, Bonavides-Martínez C, Caspi R, Fulcher C, Gama-Castro S, Kothari A, Krummenacker M, Latendresse M, Muñiz-Rascado L, Ong Q, Paley S, Peralta-Gil M, Subhraveti P, Velázquez-Ramírez DA, Weaver D, Collado-Vides J, Paulsen I, Karp PD. The EcoCyc database: reflecting new knowledge about Escherichia coli K-12. Nucleic Acids Research. 2017;45(D1):D543-D50. doi: 10.1093/nar/gkw1003.

2. Li C, Thio WJ-C, Sprott JC, Iu HH, Xu Y. Constructing Infinitely Many Attractors in a Programmable Chaotic Circuit. IEEE Access. 2018;6:29003-12. doi: 10.1109/ACCESS.2018.2824984.

3. Levin-Reisman I, Ronin I, Gefen O, Braniss I, Shoresh N, Balaban NQ. Antibiotic tolerance facilitates the evolution of resistance. Science. 2017;355(6327):826-30. Epub 2017/02/12. doi: 10.1126/science.aaj2191. PubMed PMID: 28183996.

4. El Meouche I, Dunlop MJ. Heterogeneity in efflux pump expression predisposes antibioticresistant cells to mutation. Science (New York, NY). 2018;362(6415):686-90. doi: 10.1126/science.aar7981. PubMed PMID: 30409883.

5. Hofsteenge N, van Nimwegen E, Silander OK. Quantitative analysis of persister fractions suggests different mechanisms of formation among environmental isolates of E. coli. BMC Microbiol. 2013;13:25. Epub 2013/02/06. doi: 10.1186/1471-2180-13-25. PubMed PMID: 23379956; PMCID: PMC3682893.

6. Tkachenko AG, Kashevarova NM, Karavaeva EA, Shumkov MS. Putrescine controls the formation of Escherichia coli persister cells tolerant to aminoglycoside netilmicin. FEMS Microbiol Lett. 2014;361(1):25-33. Epub 2014/10/07. doi: 10.1111/1574-6968.12613. PubMed PMID: 25283595.

7. Pu Y, Zhao Z, Li Y, Zou J, Ma Q, Zhao Y, Ke Y, Zhu Y, Chen H, Baker MAB, Ge H, Sun Y, Xie XS, Bai F. Enhanced efflux activity facilitates drug tolerance in dormant bacterial cells. Mol Cell. 2016;62(2):284-94. doi: 10.1016/j.molcel.2016.03.035.

8. Simsek E, Kim M. Power-law tail in lag time distribution underlies bacterial persistence. Proc Natl Acad Sci U S A. 2019;116(36):17635-40. Epub 2019/08/21. doi: 10.1073/pnas.1903836116. PubMed PMID: 31427535; PMCID: PMC6731627.

9. Vega NM, Allison KR, Khalil AS, Collins JJ. Signaling-mediated bacterial persister formation. Nat Chem Biol. 2012;8(5):431-3.

10. Cui P, Niu H, Shi W, Zhang S, Zhang W, Zhang Y. Identification of Genes Involved in Bacteriostatic Antibiotic-Induced Persister Formation. Front Microbiol. 2018;9:413. Epub 2018/03/22. doi: 10.3389/fmicb.2018.00413. PubMed PMID: 29559967; PMCID: PMC5845583.

11. Matsumoto S, Kawai Y, Miyagawa S, Iwamoto Y, Okuda S, Sanchez-Gorostiaga A, Vicente M, Tsuneda S. Unique transcriptional profile of native persisters in Escherichia coli. J Biosci Bioeng. 2018;125(1):15-22. Epub 2017/08/20. doi: 10.1016/j.jbiosc.2017.07.015. PubMed PMID: 28821380.

12. Harms A, Fino C, Sorensen MA, Semsey S, Gerdes K. Prophages and Growth Dynamics Confound Experimental Results with Antibiotic-Tolerant Persister Cells. MBio. 2017;8(6). Epub 2017/12/14. doi: 10.1128/mBio.01964-17. PubMed PMID: 29233898; PMCID: PMC5727415.

13. Amato SM, Orman MA, Brynildsen MP. Metabolic control of persister formation in Escherichia coli. Mol Cell. 2013;50(4):475-87, NIHMSID: 23665232. 
14. Kwan BW, Valenta JA, Benedik MJ, Wood TK. Arrested protein synthesis increases persister-like cell formation. Antimicrob Agents Chemother. 2013;57(3):1468-73. Epub 2013/01/09. doi: 10.1128/aac.02135-12. PubMed PMID: 23295927; PMCID: PMC3591907.

15. Ray JCJ, Wickersheim ML, Jalihal AP, Adeshina YO, Cooper TF, Balázsi G. Cellular growth arrest and persistence from enzyme saturation. PLoS Comput Biol. 2016;12(3):e1004825; PMCID: PMC4820279.

16. Dykhuizen D, Hartl D. Transport by the lactose permease of Escherichia coli as the basis of lactose killing. J Bacteriol. 1978;135(3):876-82; PMCID: PMC222459.

17. Eames M, Kortemme T. Cost-benefit tradeoffs in engineered lac operons. Science. 2012;336(6083):911-5, NIHMSID: 22605776.

18. Abramson J, Iwata S, Kaback HR. Lactose permease as a paradigm for membrane transport proteins. Mol Membr Biol. 2004;21(4):227-36. PubMed PMID: citeulike:12575051.

19. Bandyopadhyay A, Wang H, Ray JCJ. Lineage space and the propensity of bacterial cells to undergo growth transitions. PLoS Comput Biol. 2018;14(8):e1006380. doi: 10.1371/journal.pcbi.1006380; PMCID: PMC6122811.

20. Pruitt KD, Tatusova T, Maglott DR. NCBI reference sequences (RefSeq): a curated non-redundant sequence database of genomes, transcripts and proteins. Nucleic Acids Res. 2007;35(Database issue):D615. Epub 2006/11/30. doi: 10.1093/nar/gk1842. PubMed PMID: 17130148; PMCID: PMC1716718.

21. Bray NL, Pimentel H, Melsted P, Pachter L. Near-optimal probabilistic RNA-seq quantification. Nat Biotechnol. 2016;34(5):525-7. Epub 2016/04/05. doi: 10.1038/nbt.3519. PubMed PMID: 27043002.

22. Love MI, Huber W, Anders S. Moderated estimation of fold change and dispersion for RNA-seq data with DESeq2. Genome Biology. 2014;15(12):550. doi: 10.1186/s13059-014-0550-8.

23. Karp PD, Ong WK, Paley S, Billington R, Caspi R, Fulcher C, Kothari A, Krummenacker M, Latendresse M, Midford PE, Subhraveti P, Gama-Castro S, Muniz-Rascado L, Bonavides-Martinez C, Santos-Zavaleta A, Mackie A, Collado-Vides J, Keseler IM, Paulsen I. The EcoCyc Database. EcoSal Plus. 2018;8(1). Epub 2018/11/09. doi: 10.1128/ecosalplus.ESP-0006-2018. PubMed PMID: 30406744.

24. Lee SJ, Trostel A, Le P, Harinarayanan R, Fitzgerald PC, Adhya S. Cellular stress created by intermediary metabolite imbalances. Proceedings of the National Academy of Sciences of the United States of America. 2009;106(46):19515-20. Epub 2009/11/03. doi: 10.1073/pnas.0910586106. PubMed PMID: 19887636.

25. Lee SJ, Trostel A, Adhya S. Metabolite Changes Signal Genetic Regulatory Mechanisms for Robust Cell Behavior. mBio. 2014;5(1):e00972-13. doi: 10.1128/mBio.00972-13.

26. Lewis K. Persister cells. Annu Rev Microbiol. 2010;64:357-72, NIHMSID: 20528688.

27. Meddows TR, Savory AP, Grove JI, Moore T, Lloyd RG. RecN protein and transcription factor DksA combine to promote faithful recombinational repair of DNA double-strand breaks. Mol Microbiol. 2005;57(1):97-110. Epub 2005/06/14. doi: 10.1111/j.1365-2958.2005.04677.x. PubMed PMID: 15948952. 
28. Paget MS. Bacterial Sigma Factors and Anti-Sigma Factors: Structure, Function and Distribution. Biomolecules. 2015;5(3):1245-65. doi: 10.3390/biom5031245. PubMed PMID: 26131973.

29. Santos-Zavaleta A, Salgado H, Gama-Castro S, Sanchez-Perez M, Gomez-Romero L, LedezmaTejeida D, Garcia-Sotelo JS, Alquicira-Hernandez K, Muniz-Rascado LJ, Pena-Loredo P, Ishida-Gutierrez C, Velazquez-Ramirez DA, Del Moral-Chavez V, Bonavides-Martinez C, Mendez-Cruz CF, Galagan J, Collado-Vides J. RegulonDB v 10.5: tackling challenges to unify classic and high throughput knowledge of gene regulation in E. coli K-12. Nucleic Acids Res. 2019;47(D1):D212-d20. Epub 2018/11/06. doi: 10.1093/nar/gky1077. PubMed PMID: 30395280; PMCID: PMC6324031.

30. Nystrom T. Growth versus maintenance: a trade-off dictated by RNA polymerase availability and sigma factor competition? Mol Microbiol. 2004;54(4):855-62. Epub 2004/11/04. doi: 10.1111/j.13652958.2004.04342.x. PubMed PMID: 15522072.

31. Sanchez-Vazquez P, Dewey CN, Kitten N, Ross W, Gourse RL. Genome-wide effects on Escherichia coli transcription from ppGpp binding to its two sites on RNA polymerase. Proc Natl Acad Sci U S A. 2019;116(17):8310-9. Epub 2019/04/12. doi: 10.1073/pnas.1819682116. PubMed PMID: 30971496; PMCID: PMC6486775.

32. Riordan J, Mitra A. Regulation of Escherichia coli Pathogenesis by Alternative Sigma Factor N. EcoSal Plus. 2017. doi: doi:10.1128/ecosalplus.ESP-0016-2016.

33. Erickson JW, Gross CA. Identification of the sigma E subunit of Escherichia coli RNA polymerase: a second alternate sigma factor involved in high-temperature gene expression. Genes Dev. 1989;3(9):146271. Epub 1989/09/01. doi: 10.1101/gad.3.9.1462. PubMed PMID: 2691330.

34. Korotkevich G, Sukhov V, Budin N, Shpak B, Artyomov MN, Sergushichev A. Fast gene set enrichment analysis. bioRxiv. 2021:060012. doi: 10.1101/060012.

35. Pittard J, Yang J. Biosynthesis of the Aromatic Amino Acids. EcoSal Plus. 2008;3(1). Epub 2008/09/01. doi: 10.1128/ecosalplus.3.6.1.8. PubMed PMID: 26443741.

36. van Beilen JWA, Hellingwerf KJ. All Three Endogenous Quinone Species of Escherichia coli Are Involved in Controlling the Activity of the Aerobic/Anaerobic Response Regulator ArcA. Frontiers in microbiology. 2016;7:1339-. doi: 10.3389/fmicb.2016.01339. PubMed PMID: 27656164.

37. Stefely JA, Pagliarini DJ. Biochemistry of Mitochondrial Coenzyme Q Biosynthesis. Trends Biochem Sci. 2017;42(10):824-43. Epub 2017/09/17. doi: 10.1016/j.tibs.2017.06.008. PubMed PMID: 28927698.

38. Sévin DC, Sauer U. Ubiquinone accumulation improves osmotic-stress tolerance in Escherichia coli. Nat Chem Biol. 2014;10(4):266-72. Epub 2014/02/11. doi: 10.1038/nchembio.1437. PubMed PMID: 24509820 .

39. Begley TP, Kinsland C, Mehl RA, Osterman A, Dorrestein P. The biosynthesis of nicotinamide adenine dinucleotides in bacteria. Vitam Horm. 2001;61:103-19. Epub 2001/01/12. doi: 10.1016/s00836729(01)61003-3. PubMed PMID: 11153263.

40. Haseltine WA, Block R. Synthesis of guanosine tetra- and pentaphosphate requires the presence of a codon-specific, uncharged transfer ribonucleic acid in the acceptor site of ribosomes. Proc Natl Acad Sci 
U S A. 1973;70(5):1564-8. Epub 1973/05/01. doi: 10.1073/pnas.70.5.1564. PubMed PMID: 4576025; PMCID: PMC433543.

41. Koland JG, Miller MJ, Gennis RB. Reconstitution of the membrane-bound, ubiquinone-dependent pyruvate oxidase respiratory chain of Escherichia coli with the cytochrome $\mathrm{d}$ terminal oxidase. Biochemistry. 1984;23(3):445-53. Epub 1984/01/31. doi: 10.1021/bi00298a008. PubMed PMID: 6367818.

42. Jones RW, Lamont A, Garland PB. The mechanism of proton translocation driven by the respiratory nitrate reductase complex of Escherichia coli. Biochem J. 1980;190(1):79-94. Epub 1980/07/15. doi: 10.1042/bj1900079. PubMed PMID: 6255943; PMCID: PMC1162066.

43. Garland PB, Downie JA, Haddock BA. Proton translocation and the respiratory nitrate reductase of Escherichia coli. Biochem J. 1975;152(3):547-59. Epub 1975/12/01. doi: 10.1042/bj1520547. PubMed PMID: 5996; PMCID: PMC1172508.

44. Enoch HG, Lester RL. The role of a novel cytochrome b-containing nitrate reductase and quinone in the in vitro reconstruction of formate-nitrate reductase activity of E. coli. Biochem Biophys Res Commun. 1974;61(4):1234-41. Epub 1974/12/23. doi: 10.1016/s0006-291x(74)80416-x. PubMed PMID: 4616697.

45. Ruiz-Herrera J, DeMoss JA. Nitrate reductase complex of Escherichia coli K-12: participation of specific formate dehydrogenase and cytochrome b1 components in nitrate reduction. $\mathrm{J}$ Bacteriol. 1969;99(3):720-9. Epub 1969/09/01. PubMed PMID: 4905536; PMCID: PMC250087.

46. Lenski RE. [cited 2021]. Available from: http://myxo.css.msu.edu/ecoli/dm25liquid.html.

47. Cortay JC, Bleicher F, Duclos B, Cenatiempo Y, Gautier C, Prato JL, Cozzone AJ. Utilization of acetate in Escherichia coli: structural organization and differential expression of the ace operon. Biochimie. 1989;71(9-10):1043-9. Epub 1989/09/01. doi: 10.1016/0300-9084(89)90109-0. PubMed PMID: 2512996.

48. LaPorte DC, Walsh K, Koshland DE, Jr. The branch point effect. Ultrasensitivity and subsensitivity to metabolic control. J Biol Chem. 1984;259(22):14068-75. Epub 1984/11/25. PubMed PMID: 6389540.

49. Walsh K, Koshland DE, Jr. Determination of flux through the branch point of two metabolic cycles. The tricarboxylic acid cycle and the glyoxylate shunt. J Biol Chem. 1984;259(15):9646-54. Epub 1984/08/10. PubMed PMID: 6378912.

50. Yoon SH, Han M-J, Jeong H, Lee CH, Xia X-X, Lee D-H, Shim JH, Lee SY, Oh TK, Kim JF. Comparative multi-omics systems analysis of Escherichia coli strains B and K-12. Genome Biol. 2012;13(5):R37-R. doi: 10.1186/gb-2012-13-5-r37. PubMed PMID: 22632713.

51. Wolfe AJ. The acetate switch. Microbiol Mol Biol Rev. 2005;69(1):12-50. Epub 2005/03/10. doi: 10.1128/MMBR.69.1.12-50.2005. PubMed PMID: 15755952; PMCID: PMC1082793.

52. Basan M, Hui S, Okano H, Zhang Z, Shen Y, Williamson JR, Hwa T. Overflow metabolism in Escherichia coli results from efficient proteome allocation. Nature. 2015;528(7580):99-104. Epub 2015/12/04. doi: 10.1038/nature15765. PubMed PMID: 26632588; PMCID: PMC4843128.

53. Peebo K, Valgepea K, Maser A, Nahku R, Adamberg K, Vilu R. Proteome reallocation in Escherichia coli with increasing specific growth rate. Mol Biosyst. 2015;11(4):1184-93. Epub 2015/02/26. doi: 10.1039/c4mb00721b. PubMed PMID: 25712329. 
54. Keseler IM, Mackie A, Santos-Zavaleta A, Billington R, Bonavides-Martínez C, Caspi R, Fulcher C, Gama-Castro S, Kothari A, Krummenacker M, Latendresse M, Muñiz-Rascado L, Ong Q, Paley S, Peralta-Gil M, Subhraveti P, Velázquez-Ramírez DA, Weaver D, Collado-Vides J, Paulsen I, Karp PD. The EcoCyc database: reflecting new knowledge about Escherichia coli K-12. Nucleic Acids Research. 2016;45(D1):D543-D50. doi: 10.1093/nar/gkw1003.

55. Santos-Zavaleta A, Salgado H, Gama-Castro S, Sánchez-Pérez M, Gómez-Romero L, LedezmaTejeida D, García-Sotelo JS, Alquicira-Hernández K, Muñiz-Rascado LJ, Peña-Loredo P, Ishida-Gutiérrez C, Velázquez-Ramírez DA, Del Moral-Chávez V, Bonavides-Martínez C, Méndez-Cruz C-F, Galagan J, Collado-Vides J. RegulonDB v 10.5: tackling challenges to unify classic and high throughput knowledge of gene regulation in E. coli K-12. Nucleic acids research. 2019;47(D1):D212-D20. doi: 10.1093/nar/gky1077. PubMed PMID: 30395280.

56. Love MI, Huber W, Anders S. Moderated estimation of fold change and dispersion for RNA-seq data with DESeq2. Genome Biol. 2014;15(12):550. Epub 2014/12/18. doi: 10.1186/s13059-014-0550-8. PubMed PMID: 25516281; PMCID: PMC4302049.

57. Sha Y, Phan JH, Wang MD. Effect of low-expression gene filtering on detection of differentially expressed genes in RNA-seq data. Conf Proc IEEE Eng Med Biol Soc. 2015;2015:6461-4. Epub 2016/01/07. doi: 10.1109/EMBC.2015.7319872. PubMed PMID: 26737772; PMCID: PMC4983442.

58. Korotkevich G, Sukhov V, Sergushichev A. Fast gene set enrichment analysis. bioRxiv. 2019:060012. doi: 10.1101/060012.

59. Shannon P, Markiel A, Ozier O, Baliga NS, Wang JT, Ramage D, Amin N, Schwikowski B, Ideker T. Cytoscape: a software environment for integrated models of biomolecular interaction networks. Genome Res. 2003;13(11):2498-504. Epub 2003/11/05. doi: 10.1101/gr.1239303. PubMed PMID: 14597658; PMCID: PMC403769.

60. King ZA, Dräger A, Ebrahim A, Sonnenschein N, Lewis NE, Palsson BO. Escher: A Web Application for Building, Sharing, and Embedding Data-Rich Visualizations of Biological Pathways. PLOS Computational Biology. 2015;11(8):e1004321. doi: 10.1371/journal.pcbi.1004321. 


\section{Supplementary Figures}
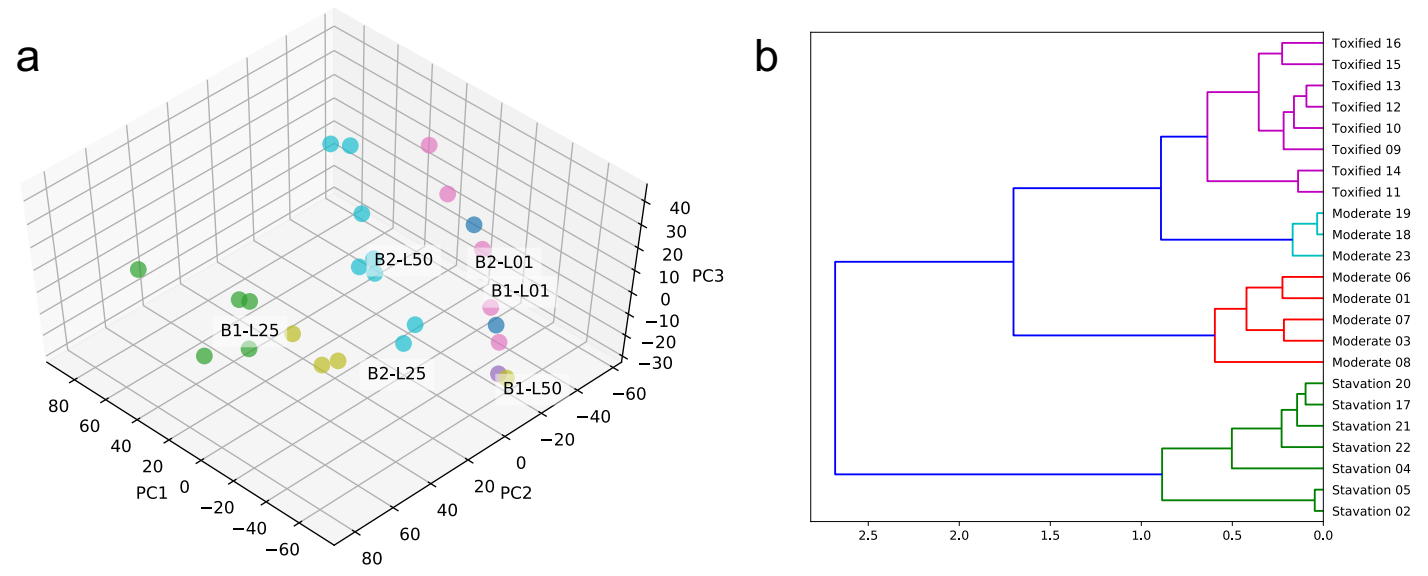

Figure S1. Data quality verification. a. PCA analysis for the transcriptome profile. b. hierarchical clustering using Wald significance. The clustering recapitulated treatment conditions.

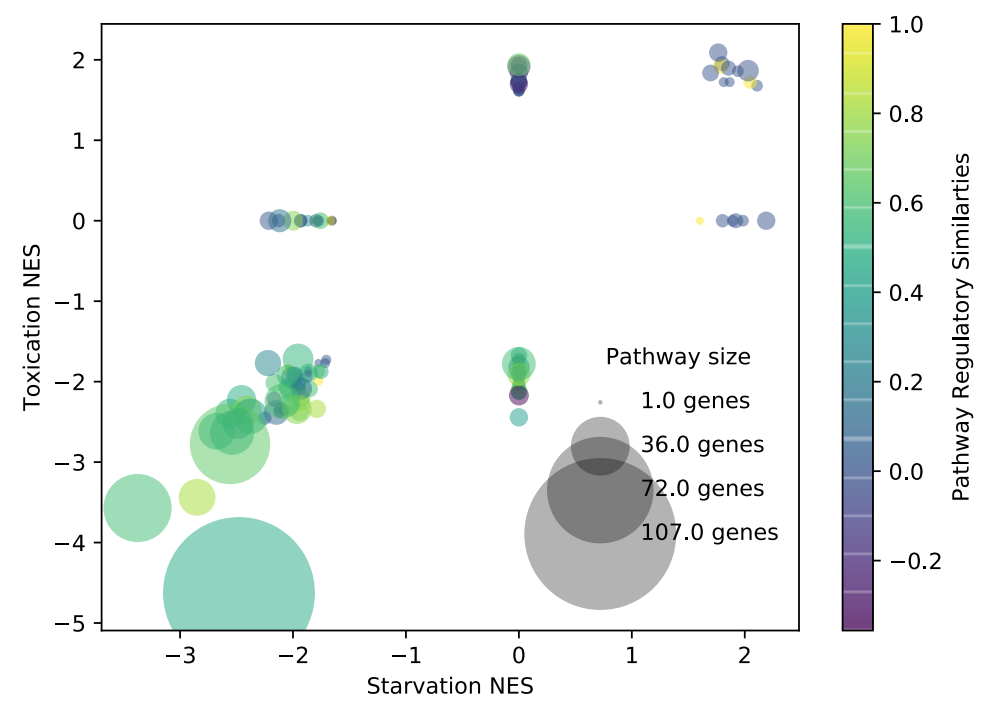

Figure S2. Pathway enrichment analysis overview. The plot is color-coded for the similarity of pathway regulation between starvation and toxicity. The size of the circle represents pathway gene set size, and the location of the bubbles are the normalized enrichment scores for each pathway. 
bioRxiv preprint doi: $h t t p s: / / d o i . o r g / 10.1101 / 2021.1217 .473201$; this version posted December 18,2021 . The copyright holder for this preprint (which was not certified by peer review) is the author/funder, who has granted bioRxiv a license to display the preprint in perpetuity. It is made available under aCC-BY 4.0 International license.
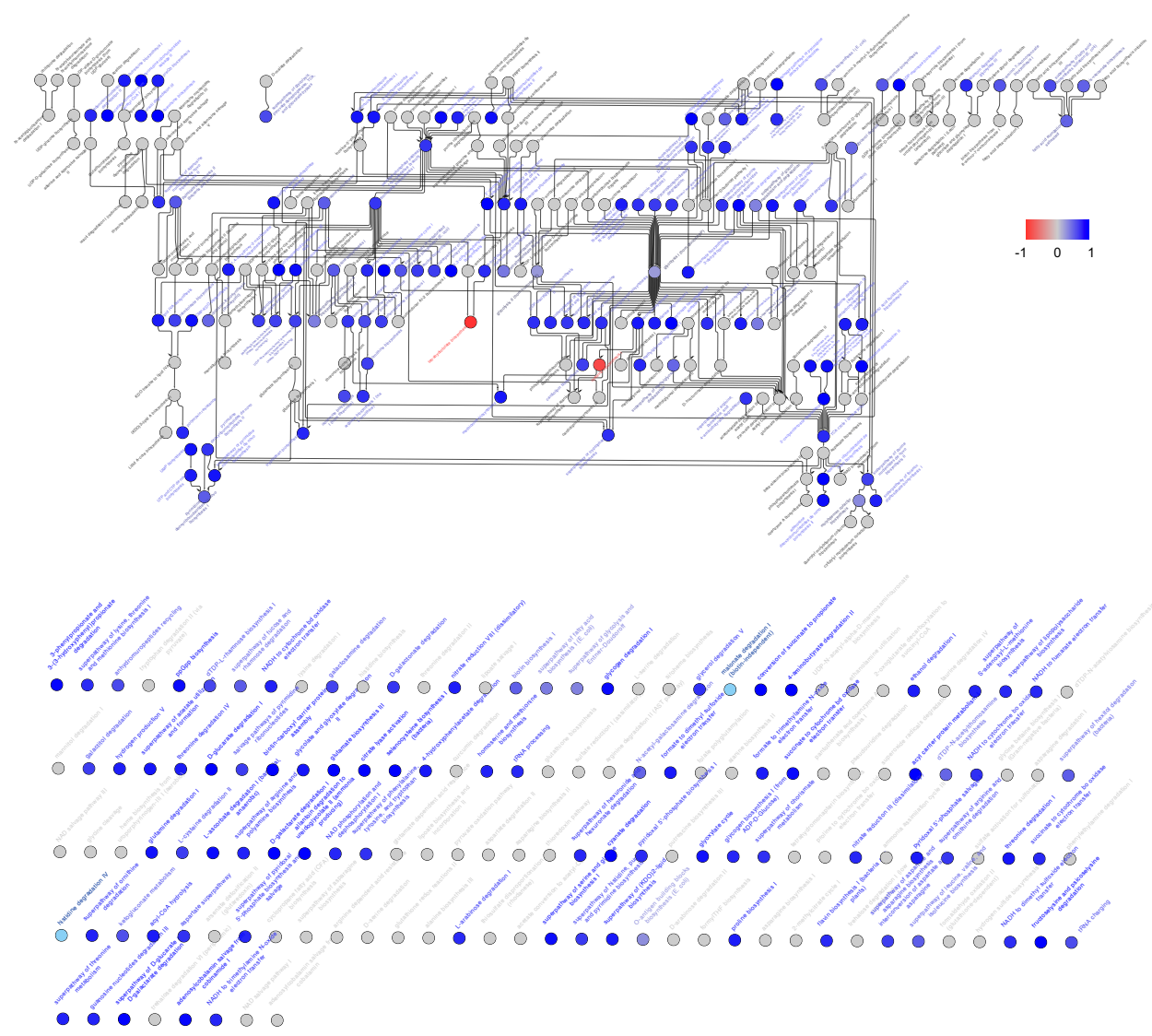

Figure S3. Pathway regulatory correlations between starving and toxified cells. Blue dots show a conserved regulatory regime for both stresses, and red dots show oppositely regulated pathways. 
bioRxiv preprint doi: https://doi.org/10.1101/2021.12.17.473201; this version posted December 18, 2021. The copyright holder for this preprint (which was not certified by peer review) is the author/funder, who has granted bioRxiv a license to display the preprint in perpetuity. It is made available under aCC-BY 4.0 International license.

\section{Supplementary Tables}

Table S1. Pathways enriched in both starvation and toxification. Pathway ID and name are according to EcoCyc database annotations, and normalized enrichment score is calculated using the R package fgsea.

\begin{tabular}{|c|c|c|c|c|c|}
\hline Pathway ID & Name & $\begin{array}{l}\text { Gene } \\
\text { Set Size }\end{array}$ & $\begin{array}{l}\text { Spearman } \\
\text { correlation }\end{array}$ & $\begin{array}{l}\text { Toxication } \\
\text { NES }\end{array}$ & $\begin{array}{l}\text { Starvation } \\
\text { NES }\end{array}$ \\
\hline PUTDEG-PWY & putrescine degradation I & 2 & -1 & 1.48002492 & 4.65997042 \\
\hline PWY0-1305 & glutamate dependent acid resistance & 2 & -1 & 1.1859878 & 1.59212915 \\
\hline PWY0-461 & lysine degradation I & 2 & -1 & 1.35155215 & 1.83928035 \\
\hline PWY0-1317 & L-lactaldehyde degradation (aerobic) & 2 & -1 & 1.46805444 & 2.01581953 \\
\hline THRDLCTCAT-PWY & $\begin{array}{l}\text { threonine degradation III (to methyl- } \\
\text { glyoxal) }\end{array}$ & 2 & -1 & 1.46828561 & 1.77182093 \\
\hline PWY0-1280 & ethylene glycol degradation & 2 & -1 & 2.32846128 & 2.44590459 \\
\hline $\begin{array}{l}\text { GLYCOLATEMET- } \\
\text { PWY }\end{array}$ & glycolate and glyoxylate degradation I & 7 & $\begin{array}{r}0.3214285 \\
7\end{array}$ & 1.88244895 & 1.86338914 \\
\hline $\begin{array}{l}\text { GLYCOL-GLY- } \\
\text { OXDEG-PWY }\end{array}$ & $\begin{array}{l}\text { superpathway of glycol metabolism } \\
\text { and degradation }\end{array}$ & 11 & $\begin{array}{r}0.3644656 \\
4 \\
\end{array}$ & 1.88372208 & 2.02611816 \\
\hline PWY0-42 & 2-methylcitrate cycle I & 6 & $\begin{array}{r}0.3714285 \\
7\end{array}$ & 1.69070836 & 2.03799995 \\
\hline PWY-6961 & $\begin{array}{l}\text { L-ascorbate degradation II (bacterial, } \\
\text { aerobic) }\end{array}$ & 9 & $\begin{array}{r}0.8333333 \\
3\end{array}$ & 2.11098325 & 1.79204893 \\
\hline PWY-6772 & hydrogen production $\mathrm{V}$ & 7 & $\begin{array}{r}0.8571428 \\
6 \\
\end{array}$ & 1.88508666 & 1.77736595 \\
\hline PWY0-301 & $\begin{array}{l}\text { L-ascorbate degradation I (bacterial, } \\
\text { anaerobic) }\end{array}$ & 8 & $\begin{array}{r}0.9523809 \\
5\end{array}$ & 1.83854381 & 1.72700654 \\
\hline LYXMET-PWY & L-lyxose degradation & 7 & $\begin{array}{r}0.9642857 \\
1 \\
\end{array}$ & 1.93769922 & 1.80519956 \\
\hline $\begin{array}{l}\text { THREONINE-DEG2- } \\
\text { PWY }\end{array}$ & threonine degradation II & 2 & 1 & 1.25911262 & 1.90509234 \\
\hline $\begin{array}{l}\text { GLUCONSUPER- } \\
\text { PWY }\end{array}$ & D-gluconate degradation & 2 & 1 & 1.702271 & 2.3647267 \\
\hline PWY-66 & $\begin{array}{l}\text { GDP-L-fucose biosynthesis I (from } \\
\text { GDP-D-mannose) }\end{array}$ & 2 & 1 & 2.99269776 & 2.42917244 \\
\hline PWY0-661 & PRPP biosynthesis II & 2 & 1 & 2.88193561 & 1.72370551 \\
\hline PWY-6894 & $\begin{array}{l}\text { thiamin diphosphate biosynthesis I (E. } \\
\text { coli) }\end{array}$ & 2 & 1 & 2.70271621 & 2.35363775 \\
\hline PWY-7181 & $\begin{array}{l}\text { pyrimidine deoxyribonucleosides deg- } \\
\text { radation }\end{array}$ & 2 & 1 & 1.15009838 & 1.93460402 \\
\hline PWY0-1300 & $\begin{array}{l}\text { 2-O-alpha-mannosyl-D-glycerate deg- } \\
\text { radation }\end{array}$ & 2 & 1 & 2.45899684 & 2.4412234 \\
\hline 2PHENDEG-PWY & phenylethylamine degradation I & 2 & 1 & 1.97359284 & 2.09844355 \\
\hline PWY0-1309 & chitobiose degradation & 2 & 1 & 1.88736692 & 1.19095321 \\
\hline TRESYN-PWY & trehalose biosynthesis I & 2 & 1 & 1.83677266 & 3.00331018 \\
\hline PWY-7247 & $\begin{array}{l}\text { beta-D-glucuronide and D-glucuronate } \\
\text { degradation }\end{array}$ & 2 & 1 & 1.82541516 & 1.60708482 \\
\hline PWY-46 & putrescine biosynthesis III & 2 & 1 & 1.78260691 & 1.40424707 \\
\hline PWY-6019 & pseudouridine degradation & 2 & 1 & 3.23424124 & 2.69738572 \\
\hline XYLCAT-PWY & xylose degradation I & 2 & 1 & 2.34239671 & 3.07625823 \\
\hline PWY0-1466 & trehalose degradation VI (periplasmic) & 2 & 1 & 1.70019343 & 4.27176029 \\
\hline PWY0-1477 & ethanolamine utilization & 2 & 1 & 2.32607631 & 1.9938891 \\
\hline $\begin{array}{l}\text { GLUCAR- } \\
\text { GALACTSUPER-PWY }\end{array}$ & $\begin{array}{l}\text { superpathway of D-glucarate and D-ga- } \\
\text { lactarate degradation }\end{array}$ & 5 & 1 & 1.85197625 & 1.98616611 \\
\hline AST-PWY & arginine degradation II (AST pathway) & 5 & 1 & 1.67181348 & 2.15994831 \\
\hline GLUCARDEG-PWY & D-glucarate degradation I & 4 & 1 & 1.69740595 & 1.84433906 \\
\hline $\begin{array}{l}\text { GALACTARDEG- } \\
\text { PWY }\end{array}$ & D-galactarate degradation I & 4 & 1 & 1.69740595 & 1.89776655 \\
\hline
\end{tabular}


bioRxiv preprint doi: https://doi.org/10.1101/2021.12.17.473201; this version posted December 18, 2021. The copyright holder for this preprint (which was not certified by peer review) is the author/funder, who has granted bioRxiv a license to display the preprint in perpetuity. It is made available under aCC-BY 4.0 International license.

\begin{tabular}{|l|l|r|l|r|r|}
\hline PWY0-541 & $\begin{array}{l}\text { cyclopropane fatty acid (CFA) biosyn- } \\
\text { thesis }\end{array}$ & 1 & NC & 1.49596218 & 1.94296286 \\
\hline TREDEGLOW-PWY & $\begin{array}{l}\text { trehalose degradation I (low osmolar- } \\
\text { ity) }\end{array}$ & 1 & NC & 2.18675062 & 1.41455366 \\
\hline PWY0-1315 & L-lactaldehyde degradation (anaerobic) & 1 & NC & 2.32846128 & 1.49622475 \\
\hline PWY-6476 & $\begin{array}{l}\text { cytidylyl molybdenum cofactor biosyn- } \\
\text { thesis }\end{array}$ & 1 & NC & 2.73758113 & 6.40687046 \\
\hline TRYPDEG-PWY & $\begin{array}{l}\text { tryptophan degradation II (via py- } \\
\text { ruvate) }\end{array}$ & 1 & NC & 2.71945032 & 2.32442325 \\
\hline PWY0-1306 & L-galactonate degradation & 1 & NC & 2.65064294 & 2.07270313 \\
\hline PWY0-1313 & acetate conversion to acetyl-CoA & 1 & NC & 1.19407481 & 4.21849854 \\
\hline PYRUVOX-PWY & pyruvate oxidation pathway & 1 & NC & 1.1743514 & 3.66245495 \\
\hline PWY0-1527 & curcumin degradation & 1 & NC & 2.09016159 & 3.65971023 \\
\hline PWY-4621 & arsenate detoxification II (glutaredoxin) & 1 & NC & 1.39610105 & 1.14732764 \\
\hline SORBDEG-PWY & D-sorbitol degradation II & 1 & NC & 1.25727254 & 1.08246131 \\
\hline
\end{tabular}


bioRxiv preprint doi: https://doi.org/10.1101/2021.12.17.473201; this version posted December 18, 2021. The copyright holder for this preprint (which was not certified by peer review) is the author/funder, who has granted bioRxiv a license to display the preprint in perpetuity. It is made available under aCC-BY 4.0 International license.

Table S2. Pathways that are downregulated in both starvation and toxification. Pathway ID and name are according to EcoCyc database annotations, and normalized enrichment score is calculated using the R package fgsea.

\begin{tabular}{|c|c|c|c|c|c|}
\hline Pathway ID & Name & $\begin{array}{l}\text { Gene Set } \\
\text { Size }\end{array}$ & $\begin{array}{l}\text { Spearman corre- } \\
\text { lation }\end{array}$ & $\begin{array}{l}\text { Toxication } \\
\text { NES }\end{array}$ & $\begin{array}{l}\text { Starvation } \\
\text { NES }\end{array}$ \\
\hline PWY-6164 & 3-dehydroquinate biosynthesis I & 4 & 0.2 & -1.7170986 & -1.6743143 \\
\hline 1CMET2-PWY & formylTHF biosynthesis & 13 & 0.21028159 & -2.5127379 & -2.2476814 \\
\hline PWY0-1544 & $\begin{array}{l}\text { proline to cytochrome bo oxidase } \\
\text { electron transfer }\end{array}$ & 5 & 0.3 & -1.8036565 & -2.0335072 \\
\hline PWY-7221 & $\begin{array}{l}\text { guanosine ribonucleotides de novo } \\
\text { biosynthesis }\end{array}$ & 4 & 0.4 & -1.9758629 & -1.7332184 \\
\hline PWY-6123 & inosine-5'-phosphate biosynthesis I & 5 & 0.4 & -2.2939608 & -2.0663072 \\
\hline $\begin{array}{l}\text { SULFATE-CYS- } \\
\text { PWY }\end{array}$ & $\begin{array}{l}\text { superpathway of sulfate assimilation } \\
\text { and cysteine biosynthesis }\end{array}$ & 14 & 0.40468084 & -1.8650526 & -2.3251339 \\
\hline $\begin{array}{l}\text { BRANCHED- } \\
\text { CHAIN-AA- } \\
\text { SYN-PWY }\end{array}$ & $\begin{array}{l}\text { superpathway of leucine, valine, and } \\
\text { isoleucine biosynthesis }\end{array}$ & 16 & 0.54411886 & -2.3907053 & -2.3628305 \\
\hline VALSYN-PWY & valine biosynthesis & 9 & 0.55064377 & -1.9802507 & -2.1931326 \\
\hline $\begin{array}{l}\text { DAP- } \\
\text { LYSINESYN- } \\
\text { PWY }\end{array}$ & lysine biosynthesis I & 11 & 0.57028521 & -2.1073292 & -1.9758616 \\
\hline THRESYN-PWY & threonine biosynthesis & 7 & 0.57659998 & -2.1819213 & -2.2058568 \\
\hline $\begin{array}{l}\text { TRNA-CHARG- } \\
\text { ING-PWY }\end{array}$ & tRNA charging & 107 & 0.62366092 & -4.4279593 & -2.5551741 \\
\hline $\begin{array}{l}\text { PEPTIDOGLY- } \\
\text { CANSYN-PWY }\end{array}$ & $\begin{array}{l}\text { peptidoglycan biosynthesis I (meso- } \\
\text { diaminopimelate containing) }\end{array}$ & 17 & 0.68697631 & -1.7201171 & -1.9180572 \\
\hline $\begin{array}{l}\text { DENOVOPU- } \\
\text { RINE2-PWY }\end{array}$ & $\begin{array}{l}\text { superpathway of purine nucleotides } \\
\text { de novo biosynthesis II }\end{array}$ & 21 & 0.68918484 & -3.4673257 & -2.8912608 \\
\hline PWY-6387 & $\begin{array}{l}\text { UDP-N-acetylmuramoyl-pentapep- } \\
\text { tide biosynthesis I (meso-DAP-con- } \\
\text { taining) }\end{array}$ & 9 & 0.69488131 & -1.8992943 & -1.8886918 \\
\hline PHESYN & phenylalanine biosynthesis I & 5 & 0.7 & -1.89207 & -1.8678241 \\
\hline ECASYN-PWY & $\begin{array}{l}\text { enterobacterial common antigen bio- } \\
\text { synthesis }\end{array}$ & 11 & 0.7054586 & -1.9152036 & -2.1115153 \\
\hline LEUSYN-PWY & leucine biosynthesis & 6 & 0.71428571 & -2.1173865 & -1.9587867 \\
\hline PRPP-PWY & $\begin{array}{l}\text { superpathway of histidine, purine, } \\
\text { and pyrimidine biosynthesis }\end{array}$ & 43 & 0.72091986 & -3.5866655 & -3.2680707 \\
\hline PWY-6628 & $\begin{array}{l}\text { superpathway of phenylalanine bio- } \\
\text { synthesis }\end{array}$ & 16 & 0.7363165 & -2.4289374 & -2.510254 \\
\hline ARO-PWY & chorismate biosynthesis I & 11 & 0.73973495 & -1.941385 & -2.1526856 \\
\hline PWY0-781 & aspartate superpathway & 26 & 0.75367693 & -2.6576584 & -2.5798931 \\
\hline $\begin{array}{l}\text { COMPLETE- } \\
\text { ARO-PWY }\end{array}$ & $\begin{array}{l}\text { superpathway of phenylalanine, ty- } \\
\text { rosine, and tryptophan biosynthesis }\end{array}$ & 21 & 0.75932767 & -2.6053657 & -2.7188438 \\
\hline PWY0-1335 & $\begin{array}{l}\text { NADH to cytochrome bo oxidase } \\
\text { electron transfer }\end{array}$ & 17 & 0.76444213 & -2.5689955 & -2.4393504 \\
\hline PWY-6126 & $\begin{array}{l}\text { superpathway of adenosine nucleo- } \\
\text { tides de novo biosynthesis II }\end{array}$ & 9 & 0.76666667 & -2.3916299 & -1.97031 \\
\hline $\begin{array}{l}\text { ALL-CHORIS- } \\
\text { MATE-PWY }\end{array}$ & $\begin{array}{l}\text { superpathway of chorismate metabo- } \\
\text { lism }\end{array}$ & 52 & 0.77022278 & -2.8102534 & -2.5571267 \\
\hline PWY-6629 & $\begin{array}{l}\text { superpathway of tryptophan biosyn- } \\
\text { thesis }\end{array}$ & 16 & 0.77309995 & -2.2557452 & -2.4093065 \\
\hline P4-PWY & $\begin{array}{l}\text { superpathway of lysine, threonine } \\
\text { and methionine biosynthesis I }\end{array}$ & 20 & 0.79094258 & -2.4644023 & -2.3595712 \\
\hline $\begin{array}{l}\text { PYRIDOXSYN- } \\
\text { PWY }\end{array}$ & $\begin{array}{l}\text { pyridoxal 5'-phosphate biosynthesis } \\
\text { I }\end{array}$ & 7 & 0.79282497 & -1.992129 & -1.9864921 \\
\hline TYRSYN & tyrosine biosynthesis I & 4 & 0.8 & -1.7577619 & -1.6842574 \\
\hline PWY0-1329 & $\begin{array}{l}\text { succinate to cytochrome bo oxidase } \\
\text { electron transfer }\end{array}$ & 8 & 0.80511756 & -1.9386191 & -2.0145265 \\
\hline PWY0-1479 & tRNA processing & 8 & 0.80995314 & -2.214798 & -1.9543398 \\
\hline
\end{tabular}


bioRxiv preprint doi: https://doi.org/10.1101/2021.12.17.473201; this version posted December 18, 2021. The copyright holder for this preprint (which was not certified by peer review) is the author/funder, who has granted bioRxiv a license to display the preprint in perpetuity. It is made available under aCC-BY 4.0 International license.

\begin{tabular}{|c|c|c|c|c|c|}
\hline LPSSYN-PWY & $\begin{array}{l}\text { superpathway of lipopolysaccharide } \\
\text { biosynthesis }\end{array}$ & 20 & 0.81108643 & -2.2741008 & -2.1287715 \\
\hline PWY0-845 & $\begin{array}{l}\text { superpathway of pyridoxal 5'-phos- } \\
\text { phate biosynthesis and salvage }\end{array}$ & 9 & 0.8136762 & -2.0845593 & -2.0788978 \\
\hline MET-SAM-PWY & $\begin{array}{l}\text { superpathway of S-adenosyl-L-me- } \\
\text { thionine biosynthesis }\end{array}$ & 11 & 0.83541781 & -2.1197985 & -2.0682583 \\
\hline METSYN-PWY & $\begin{array}{l}\text { homoserine and methionine biosyn- } \\
\text { thesis }\end{array}$ & 10 & 0.83637445 & -1.9654649 & -2.0024894 \\
\hline PWY-6125 & $\begin{array}{l}\text { superpathway of guanosine nucleo- } \\
\text { tides de novo biosynthesis II }\end{array}$ & 9 & 0.84519568 & -2.3505158 & -1.8166431 \\
\hline $\begin{array}{l}\text { KDO- } \\
\text { NAGLIPASYN- } \\
\text { PWY }\end{array}$ & $\begin{array}{l}\text { superpathway of (KDO)2-lipid A bi- } \\
\text { osynthesis }\end{array}$ & 16 & 0.88141026 & -2.3873531 & -2.0658268 \\
\hline PWY-6277 & $\begin{array}{l}\text { superpathway of 5-aminoimidazole } \\
\text { ribonucleotide biosynthesis }\end{array}$ & 6 & 0.88571429 & -2.481489 & -2.2668217 \\
\hline PWY-6122 & $\begin{array}{l}\text { 5-aminoimidazole ribonucleotide bi- } \\
\text { osynthesis II }\end{array}$ & 5 & 0.9 & -2.2787075 & -2.1128649 \\
\hline PWY-6121 & $\begin{array}{l}\text { 5-aminoimidazole ribonucleotide bi- } \\
\text { osynthesis I }\end{array}$ & 5 & 0.9 & -2.3204882 & -2.1098019 \\
\hline PWY0-162 & $\begin{array}{l}\text { superpathway of pyrimidine ribonu- } \\
\text { cleotides de novo biosynthesis }\end{array}$ & 11 & 0.90545284 & -2.313524 & -2.0679254 \\
\hline $\begin{array}{l}\text { GLU- } \\
\text { TAMINDEG- } \\
\text { PWY }\end{array}$ & glutamine degradation I & 9 & 0.91538573 & -2.2115874 & -1.9595464 \\
\hline PWY-5686 & UMP biosynthesis & 8 & 0.9187082 & -2.0578243 & -1.8682132 \\
\hline $\begin{array}{l}\text { SER-GLYSYN- } \\
\text { PWY }\end{array}$ & $\begin{array}{l}\text { superpathway of serine and glycine } \\
\text { biosynthesis I }\end{array}$ & 6 & 0.94112395 & -1.8912768 & -1.769186 \\
\hline PWY-7343 & UDP-glucose biosynthesis & 2 & 1 & -1.7850793 & -1.699465 \\
\hline PWY-6605 & adenine and adenosine salvage II & 2 & 1 & -1.9327137 & -3.38289 \\
\hline $\begin{array}{l}\text { HOMOSER- } \\
\text { THRESYN-PWY }\end{array}$ & $\begin{array}{l}\text { threonine biosynthesis from ho- } \\
\text { moserine }\end{array}$ & 2 & 1 & -1.9119924 & -3.4803336 \\
\hline $\begin{array}{l}\text { MALATE-AS- } \\
\text { PARTATE- } \\
\text { SHUTTLE-PWY }\end{array}$ & aspartate degradation II & 2 & 1 & -1.7983406 & -3.8467327 \\
\hline PWY-5965 & fatty acid biosynthesis initiation III & 2 & 1 & -1.4155951 & -1.7037825 \\
\hline PWY-2161 & folate polyglutamylation & 2 & 1 & -1.7341271 & -3.3131773 \\
\hline PWY-901 & methylglyoxal degradation II & 2 & 1 & -1.5556089 & -1.6559264 \\
\hline PWY-4381 & fatty acid biosynthesis initiation I & 2 & 1 & -1.7069039 & -1.4797282 \\
\hline $\begin{array}{l}\text { GLUTSYNIII- } \\
\text { PWY }\end{array}$ & glutamate biosynthesis III & 3 & 1 & -1.8900618 & -1.8192044 \\
\hline $\begin{array}{l}\text { AMMASSIM- } \\
\text { PWY }\end{array}$ & ammonia assimilation cycle III & 3 & 1 & -1.8571243 & -1.8192044 \\
\hline PWY-7335 & $\begin{array}{l}\text { UDP-N-acetyl-alpha-D-mannosami- } \\
\text { nouronate biosynthesis }\end{array}$ & 2 & 1 & -1.4983814 & -2.6058321 \\
\hline $\begin{array}{l}\text { GLUTAMINE- } \\
\text { FUM-PWY }\end{array}$ & glutamine degradation II & 2 & 1 & -2.8905575 & -4.8939616 \\
\hline PWY-7219 & $\begin{array}{l}\text { adenosine ribonucleotides de novo } \\
\text { biosynthesis }\end{array}$ & 3 & 1 & -1.7681931 & -1.7327185 \\
\hline GLUTSYN-PWY & glutamate biosynthesis I & 2 & 1 & -2.8905575 & -4.8939616 \\
\hline $\begin{array}{l}\text { THIOREDOX- } \\
\text { PWY }\end{array}$ & thioredoxin pathway & 1 & $\mathrm{NC}$ & -1.651714 & -3.7466738 \\
\hline $\begin{array}{l}\text { ASPAR- } \\
\text { TATESYN-PWY }\end{array}$ & aspartate biosynthesis & 1 & $\mathrm{NC}$ & -1.7983406 & -3.8467327 \\
\hline GLYSYN-PWY & glycine biosynthesis I & 1 & $\mathrm{NC}$ & -2.9459969 & -5.7535018 \\
\hline PWY-5785 & $\begin{array}{l}\text { di-trans,poly-cis-undecaprenyl phos- } \\
\text { phate biosynthesis }\end{array}$ & 1 & $\mathrm{NC}$ & -1.3916115 & -2.277032 \\
\hline PWY0-662 & PRPP biosynthesis I & 1 & $\mathrm{NC}$ & -2.9390604 & -4.2513074 \\
\hline SAM-PWY & $\begin{array}{l}\text { S-adenosyl-L-methionine biosynthe- } \\
\text { sis }\end{array}$ & 1 & $\mathrm{NC}$ & -1.9408047 & -2.4097819 \\
\hline
\end{tabular}


bioRxiv preprint doi: https://doi.org/10.1101/2021.12 17.473201; this version posted December 18, 2021. The copyright holder for this preprint (which was not certified by peer review) is the author/funder, who has granted bioRxiv a license to display the preprint in perpetuity. It is made available under aCC-BY 4.0 International license.

\begin{tabular}{|l|l|r|l|r|r|}
\hline PWY-6268 & $\begin{array}{l}\text { adenosylcobalamin salvage from co- } \\
\text { balamin }\end{array}$ & 1 & NC & -1.1325597 & -1.9376787 \\
\hline KDOSYN-PWY & KDO transfer to lipid IVA I & 1 & NC & -1.1913758 & -1.2113179 \\
\hline PWY-6617 & $\begin{array}{l}\text { adenosine nucleotides degradation } \\
\text { III }\end{array}$ & 1 & NC & -1.2055085 & -1.717672 \\
\hline $\begin{array}{l}\text { BSUBPOLYAM- } \\
\text { SYN-PWY }\end{array}$ & spermidine biosynthesis I & 1 & NC & -1.9988552 & -3.7014181 \\
\hline GLNSYN-PWY & glutamine biosynthesis I & 1 & NC & -2.0239153 & -4.9118033 \\
\hline
\end{tabular}


bioRxiv preprint doi: https://doi.org/10 1101/2021.12.17.473201: this version posted December 18, 2021. The copyright holder for this preprint (which was not certified by peer review) is the author/funder, who has granted bioRxiv a license to display the preprint in perpetuity. It is made available under aCC-BY 4.0 International license.

Table S3. Pathways uniquely enriched in starvation. Pathway ID and name are according to EcoCyc database annotations, and normalized enrichment score is calculated using the R package fgsea.

\begin{tabular}{|c|c|c|c|c|c|}
\hline Pathway ID & Name & $\begin{array}{l}\text { Gene Set } \\
\text { Size }\end{array}$ & $\begin{array}{l}\text { Spearman cor- } \\
\text { relation }\end{array}$ & $\begin{array}{l}\text { Toxication } \\
\text { NES } \\
\end{array}$ & $\begin{array}{l}\text { Starvation } \\
\text { NES }\end{array}$ \\
\hline FAO-PWY & fatty acid beta-oxidation I & 9 & -0.0666667 & 0 & 2.22387757 \\
\hline PWY-4261 & glycerol degradation I & 5 & 0.5 & 0 & 2.03254717 \\
\hline PWY0-1182 & trehalose degradation II (trehalase) & 3 & 0.5 & 0 & 1.62706335 \\
\hline PWY-6952 & glycerophosphodiester degradation & 6 & 0.71428571 & 0 & 1.79463742 \\
\hline PWY0-381 & $\begin{array}{l}\text { glycerol and glycerophosphodiester degra- } \\
\text { dation }\end{array}$ & 7 & 0.75678747 & 0 & 1.92648052 \\
\hline $\begin{array}{l}\text { GLYOXDEG- } \\
\text { PWY }\end{array}$ & glycolate and glyoxylate degradation II & 5 & 0.9 & 0 & 1.93846673 \\
\hline PWY0-1299 & arginine dependent acid resistance & 2 & 1 & 0 & 1.19479501 \\
\hline $\begin{array}{l}\text { DARABCAT- } \\
\text { PWY }\end{array}$ & D-arabinose degradation II & 1 & $\mathrm{NC}$ & 0 & 1.26124042 \\
\hline PWY-7346 & $\begin{array}{l}\text { UDP-alpha-D-glucuronate biosynthesis } \\
\text { (from UDP-glucose) }\end{array}$ & 1 & $\mathrm{NC}$ & 0 & 2.0622656 \\
\hline PWY0-1337 & oleate beta-oxidation & 1 & $\mathrm{NC}$ & 0 & 3.74727095 \\
\hline $\begin{array}{l}\text { MANNIDEG- } \\
\text { PWY }\end{array}$ & mannitol degradation I & 1 & $\mathrm{NC}$ & 0 & 3.20579409 \\
\hline $\begin{array}{l}\text { GLUAMCAT- } \\
\text { PWY }\end{array}$ & N-acetylglucosamine degradation I & 2 & $\mathrm{NC}$ & 0 & 1.21830745 \\
\hline PWY-7179 & purine deoxyribonucleosides degradation & 2 & $\mathrm{NC}$ & 0 & 1.39473893 \\
\hline PWY-6028 & acetoin degradation & 2 & $\mathrm{NC}$ & 0 & 1.47252358 \\
\hline
\end{tabular}


bioRxiv preprint doi: https://doi.org/10.1101/2021.12.17.473201; this version posted December 18, 2021. The copyright holder for this preprint (which was not certified by peer review) is the author/funder, who has granted bioRxiv a license to display the preprint in perpetuity. It is made available under aCC-BY 4.0 International license.

Table S4. Pathways that are uniquely downregulated in starvation. Pathway ID and name are according to EcoCyc database annotations, and normalized enrichment score is calculated using the R package fgsea.

\begin{tabular}{|c|c|c|c|c|c|}
\hline Pathway ID & Name & $\begin{array}{l}\text { Gene } \\
\text { Set Size }\end{array}$ & $\begin{array}{l}\begin{array}{l}\text { Spearman } \\
\text { correlation }\end{array} \\
\end{array}$ & $\begin{array}{l}\text { Toxication } \\
\text { NES } \\
\end{array}$ & $\begin{array}{l}\text { Starvation } \\
\text { NES }\end{array}$ \\
\hline GLYCLEAV-PWY & glycine cleavage & 4 & -0.2108185 & 0 & -1.7444687 \\
\hline BETSYN-PWY & $\begin{array}{l}\text { glycine betaine biosynthesis I (Gram- } \\
\text { negative bacteria) }\end{array}$ & 2 & -1 & 0 & -1.5956464 \\
\hline PWYCQD-2 & dTDP-N-acetylviosamine biosynthesis & 6 & 0.13093073 & 0 & -1.9469392 \\
\hline OANTIGEN-PWY-1 & $\begin{array}{l}\text { O-antigen building blocks biosynthesis } \\
\text { (E. coli) }\end{array}$ & 12 & 0.30623505 & 0 & -2.2262838 \\
\hline $\begin{array}{l}\text { GALACTMETAB- } \\
\text { PWY }\end{array}$ & galactose degradation I (Leloir pathway) & 5 & 0.3354102 & 0 & -1.8345093 \\
\hline SO4ASSIM-PWY & sulfate reduction I (assimilatory) & 6 & 0.3927922 & 0 & -2.1430812 \\
\hline $\begin{array}{l}\text { PYRUVDEHYD- } \\
\text { PWY }\end{array}$ & pyruvate decarboxylation to acetyl CoA & 3 & 0.5 & 0 & -1.6142377 \\
\hline PWY-5084 & $\begin{array}{l}\text { 2-oxoglutarate decarboxylation to suc- } \\
\text { cinyl-CoA }\end{array}$ & 3 & 0.5 & 0 & -1.6142377 \\
\hline PWY-7315 & dTDP-N-acetylthomosamine biosynthesis & 6 & 0.50709255 & 0 & -1.8100348 \\
\hline PWY-7184 & $\begin{array}{l}\text { pyrimidine deoxyribonucleotides de novo } \\
\text { biosynthesis I }\end{array}$ & 8 & 0.54802458 & 0 & -1.7702754 \\
\hline ILEUSYN-PWY & isoleucine biosynthesis I (from threonine) & 10 & 0.65229728 & 0 & -2.0483919 \\
\hline $\begin{array}{l}\text { DTDPRHAMSYN- } \\
\text { PWY }\end{array}$ & dTDP-L-rhamnose biosynthesis I & 6 & 0.65465367 & 0 & -1.9469392 \\
\hline $\begin{array}{l}\text { HOMOSERSYN- } \\
\text { PWY }\end{array}$ & homoserine biosynthesis & 4 & 0.73786479 & 0 & -1.6251729 \\
\hline TRPSYN-PWY & tryptophan biosynthesis & 5 & 0.82078268 & 0 & -1.7667447 \\
\hline $\begin{array}{l}\text { ASPARAGINESYN- } \\
\text { PWY }\end{array}$ & asparagine biosynthesis II & 2 & 1 & 0 & -1.9602794 \\
\hline PWY-6890 & $\begin{array}{l}\text { 4-amino-2-methyl-5-diphosphomethylpy- } \\
\text { rimidine biosynthesis }\end{array}$ & 2 & 1 & 0 & -1.0344595 \\
\hline PWY0-1325 & superpathway of asparagine biosynthesis & 2 & 1 & 0 & -1.9602794 \\
\hline PWY-6700 & queuosine biosynthesis & 4 & 1 & 0 & -1.6297352 \\
\hline HISTSYN-PWY & histidine biosynthesis & 9 & $\mathrm{NC}$ & 0 & -2.2452096 \\
\hline PWY-7344 & UDP-D-galactose biosynthesis & 1 & $\mathrm{NC}$ & 0 & -3.9647485 \\
\hline PWY0-1517 & sedoheptulose bisphosphate bypass & 2 & $\mathrm{NC}$ & 0 & -2.3330402 \\
\hline PWY0-501 & lipoate biosynthesis and incorporation I & 2 & $\mathrm{NC}$ & 0 & -1.1472346 \\
\hline $\begin{array}{l}\text { GLUTATHI- } \\
\text { ONESYN-PWY }\end{array}$ & glutathione biosynthesis & 2 & $\mathrm{NC}$ & 0 & -1.4696166 \\
\hline PWY0-1275 & lipoate biosynthesis and incorporation II & 2 & $\mathrm{NC}$ & 0 & -1.3449008 \\
\hline PWY-6618 & guanine and guanosine salvage III & 1 & $\mathrm{NC}$ & 0 & -1.4832385 \\
\hline PWY0-522 & lipoate salvage I & 1 & $\mathrm{NC}$ & 0 & -1.3449008 \\
\hline $\begin{array}{l}\text { SALVPURINE2- } \\
\text { PWY }\end{array}$ & xanthine and xanthosine salvage & 1 & $\mathrm{NC}$ & 0 & -2.0936911 \\
\hline $\begin{array}{l}\text { ASPARAGINE-BIO- } \\
\text { SYNTHESIS }\end{array}$ & asparagine biosynthesis I & 1 & $\mathrm{NC}$ & 0 & -2.1628747 \\
\hline $\begin{array}{l}\text { GLUT-REDOX- } \\
\text { PWY }\end{array}$ & glutathione redox reactions II & 1 & $\mathrm{NC}$ & 0 & -1.2122565 \\
\hline PWY0-1295 & pyrimidine ribonucleosides degradation & 2 & $\mathrm{NC}$ & 0 & -1.4918647 \\
\hline PWY-5340 & sulfate activation for sulfonation & 3 & $\mathrm{NC}$ & 0 & -1.6277355 \\
\hline
\end{tabular}


bioRxiv preprint doi: https://doi.org/10.1101/2021.12.17.473201: this version posted December 18, 2021. The copyright holder for this preprint (which was not certified by peer review) is the author/funder, who has granted bioRxiv a license to display the preprint in perpetuity. It is made available under aCC-BY 4.0 International license.

Table S5. Pathways that are uniquely enriched in toxicity. Pathway ID and name are according to EcoCyc database annotations, and normalized enrichment score is calculated using the R package fgsea.

\begin{tabular}{|c|c|c|c|c|c|}
\hline Pathway ID & Name & $\begin{array}{l}\text { Gene } \\
\text { Set } \\
\text { Size } \\
\end{array}$ & $\begin{array}{l}\text { Spearman } \\
\text { correlation }\end{array}$ & $\begin{array}{l}\text { Toxicity } \\
\text { NES }\end{array}$ & $\begin{array}{l}\text { Starva- } \\
\text { tion NES }\end{array}$ \\
\hline PWYCQD-3 & $\mathrm{N}$-acetyl-galactosamine degradation & 9 & 0.51666667 & 1.84151128 & 0 \\
\hline PWYCQD-4 & galactosamine degradation & 8 & 0.66666667 & 1.9179961 & 0 \\
\hline $\begin{array}{l}\text { GALACTITOLCAT- } \\
\text { PWY }\end{array}$ & galactitol degradation & 5 & 0.7 & 1.59677363 & 0 \\
\hline PWY0-1321 & nitrate reduction III (dissimilatory) & 12 & 0.8041958 & 1.90376903 & 0 \\
\hline $\begin{array}{l}\text { 3-HYDROXY- } \\
\text { PHENYLACETATE- } \\
\text { DEGRADATION-PWY } \\
\end{array}$ & 4-hydroxyphenylacetate degradation & 8 & 0.88095238 & 1.73575101 & 0 \\
\hline PWY0-1356 & $\begin{array}{l}\text { formate to dimethyl sulfoxide elec- } \\
\text { tron transfer }\end{array}$ & 9 & 0.88333333 & 1.69948976 & 0 \\
\hline PWY-6690 & $\begin{array}{l}\text { cinnamate and 3-hydroxycinnamate } \\
\text { degradation to 2-oxopent-4-enoate }\end{array}$ & 8 & 0.92857143 & 1.72900525 & 0 \\
\hline HCAMHPDEG-PWY & $\begin{array}{l}\text { 3-phenylpropanoate and 3-(3-hy- } \\
\text { droxyphenyl)propanoate degrada- } \\
\text { tion to 2-oxopent-4-enoate }\end{array}$ & 8 & 0.92857143 & 1.72900525 & 0 \\
\hline PWY0-1277 & $\begin{array}{l}\text { 3-phenylpropionate and 3-(3-hy- } \\
\text { droxyphenyl)propionate degradation }\end{array}$ & 12 & 0.97022916 & 1.92679151 & 0 \\
\hline RHAMCAT-PWY & L-rhamnose degradation I & 4 & 1 & 1.58032918 & 0 \\
\hline PWY0-1465 & D-malate degradation & 1 & $\mathrm{NC}$ & 1.36929171 & 0 \\
\hline PWY0-981 & taurine degradation IV & 1 & $\mathrm{NC}$ & 1.33115815 & 0 \\
\hline
\end{tabular}


bioRxiv preprint doi: https://doi.org/10.1101/2021.12.17.473201; this version posted December 18, 2021. The copyright holder for this preprint (which was not certified by peer review) is the author/funder, who has granted bioRxiv a license to display the preprint in perpetuity. It is made available under aCC-BY 4.0 International license.

Table S6. Pathways that are uniquely downregulated in toxification condition. Pathway ID and name are consistent with EcoCyc database annotations, and normalized enrichment score is calculated with R package fgsea.

\begin{tabular}{|c|c|c|c|c|c|}
\hline Pathway ID & Name & $\begin{array}{l}\text { Gene Set } \\
\text { Size }\end{array}$ & $\begin{array}{l}\text { Spearman } \\
\text { correlation }\end{array}$ & $\begin{array}{l}\text { Toxication } \\
\text { NES }\end{array}$ & $\begin{array}{l}\text { Starva- } \\
\text { tion } \\
\text { NES }\end{array}$ \\
\hline PWY-5188 & $\begin{array}{l}\text { tetrapyrrole biosynthesis I (from gluta- } \\
\text { mate) }\end{array}$ & 10 & 0 & -2.1828993 & 0 \\
\hline PWY0-1061 & superpathway of alanine biosynthesis & 8 & 0.22094698 & -1.8691385 & 0 \\
\hline PWY0-881 & $\begin{array}{l}\text { superpathway of fatty acid biosynthesis I } \\
\text { (E. coli) }\end{array}$ & 9 & 0.39167473 & -2.4002279 & 0 \\
\hline PWY0-862 & cis-dodecenoyl biosynthesis & 5 & 0.46169026 & -1.9822633 & 0 \\
\hline PWY-5989 & $\begin{array}{l}\text { stearate biosynthesis II (bacteria and } \\
\text { plants) }\end{array}$ & 5 & 0.46169026 & -1.9764809 & 0 \\
\hline $\begin{array}{l}\text { FASYN-ELONG- } \\
\text { PWY }\end{array}$ & fatty acid elongation -- saturated & 7 & 0.51887452 & -2.1586643 & 0 \\
\hline PWY-5973 & cis-vaccenate biosynthesis & 7 & 0.52357031 & -2.0937013 & 0 \\
\hline $\begin{array}{l}\text { BIOTIN-BIOSYN- } \\
\text { THESIS-PWY }\end{array}$ & biotin biosynthesis I & 11 & 0.54067025 & -1.7848757 & 0 \\
\hline PWY-5971 & $\begin{array}{l}\text { palmitate biosynthesis II (bacteria and } \\
\text { plants) }\end{array}$ & 6 & 0.5768179 & -1.9822633 & 0 \\
\hline PWY-6284 & $\begin{array}{l}\text { superpathway of unsaturated fatty acids } \\
\text { biosynthesis (E. coli) }\end{array}$ & 8 & 0.59971229 & -2.0838521 & 0 \\
\hline $\begin{array}{l}\text { FASYN-INITIAL- } \\
\text { PWY }\end{array}$ & $\begin{array}{l}\text { superpathway of fatty acid biosynthesis } \\
\text { initiation (E. coli) }\end{array}$ & 4 & 0.63245553 & -1.8415528 & 0 \\
\hline PWY0-163 & $\begin{array}{l}\text { salvage pathways of pyrimidine ribonu- } \\
\text { cleotides }\end{array}$ & 7 & 0.70418685 & -1.8942574 & 0 \\
\hline ARGSYN-PWY & arginine biosynthesis I (via L-ornithine) & 11 & 0.7723047 & -1.7913983 & 0 \\
\hline PWY0-166 & $\begin{array}{l}\text { superpathway of pyrimidine deoxyribo- } \\
\text { nucleotides de novo biosynthesis (E. coli) }\end{array}$ & 12 & 0.80049837 & -1.9230626 & 0 \\
\hline TCA & TCA cycle I (prokaryotic) & 19 & 0.80158908 & -1.7796264 & 0 \\
\hline PWY-7220 & $\begin{array}{l}\text { adenosine deoxyribonucleotides de novo } \\
\text { biosynthesis II }\end{array}$ & 6 & 0.94285714 & -1.9280087 & 0 \\
\hline PWY-7222 & $\begin{array}{l}\text { guanosine deoxyribonucleotides de novo } \\
\text { biosynthesis II }\end{array}$ & 6 & 0.94285714 & -1.9280087 & 0 \\
\hline GLUTDEG-PWY & glutamate degradation II & 2 & 1 & -1.7983406 & 0 \\
\hline PWY0-1534 & hydrogen sulfide biosynthesis I & 2 & 1 & -1.7983406 & 0 \\
\hline PWY-5123 & $\begin{array}{l}\text { trans, trans-farnesyl diphosphate biosyn- } \\
\text { thesis }\end{array}$ & 2 & 1 & -1.2644685 & 0 \\
\hline PWY0-1221 & putrescine degradation II & 4 & 1 & -1.7084731 & 0 \\
\hline PWY0-1021 & alanine biosynthesis III & 2 & $\mathrm{NC}$ & -1.8282391 & 0 \\
\hline $\begin{array}{l}\text { ALANINE-SYN2- } \\
\text { PWY }\end{array}$ & alanine biosynthesis II & 2 & $\mathrm{NC}$ & -1.0738934 & 0 \\
\hline PWY0-1433 & tetrahydromonapterin biosynthesis & 2 & $\mathrm{NC}$ & -1.4665294 & 0 \\
\hline PWY-5783 & octaprenyl diphosphate biosynthesis & 1 & $\mathrm{NC}$ & -1.1969374 & 0 \\
\hline
\end{tabular}

